Article

\title{
Bioenergy Potential and Utilization Costs for the Supply of Forest Woody Biomass for Energetic Use at a Regional Scale in Mexico
}

\author{
Ulises Flores Hernández ${ }^{1, *}$ (D), Dirk Jaeger ${ }^{1}$ and Jorge Islas Samperio ${ }^{2}$ \\ 1 Chair of Forest Operations, University of Freiburg, Freiburg im Breisgau 79085, Germany; \\ dirk.jaeger@foresteng.uni-freiburg.de \\ 2 Instituto de Energías Renovables, Universidad Nacional Autónoma de México, \\ Temixco Morelos 62580, Mexico; jis@ier.unam.mx \\ * Correspondence: ulises.flores@foresteng.uni-freiburg.de; Tel.: +49-(0)761-203-3790
}

Received: 11 July 2017; Accepted: 8 August 2017; Published: 12 August 2017

\begin{abstract}
While considering constraints in regard to sustainability, this paper reviews the development of a methodology to assess the introduction of bioenergy supply chains in Mexico based on forest woody biomass. Three research modules include analyses of forest biomass utilization residues that originated from: (1) harvesting activities, (2) non-extracted stands and (3) sawmills. A regional case study focusing on tree species of commercial importance (pine, oak and fir) in the 10 provinces with the highest timber production located in the north and central-south part of the country, is analyzed. After applying the methodology, the theoretical potential of available woody biomass for energetic use amounts to $6,357,482 \mathrm{~m}^{3}$. When applying the sustainability constraints, the technically feasible supply of forest woody biomass for energetic use sums up to $5,798,722 \mathrm{~m}^{3}$, which relate to a technical energy potential of 45.96 PJ for 2013. Moreover, a biomass energy flow chart showing energy values for each analyzed source and species is presented. Monte Carlo simulations were carried out for each cost involved in utilizing the resulting available woody biomass for energetic use. In the absence of national studies which include forest operations and bioenergy transformation to calculate the sustainable energy potential, the developed methodology adds innovation for assessing woody biomass availability.
\end{abstract}

Keywords: bioenergy; energy supply chain; Mexico; sustainable forest utilization

\section{Introduction}

The state of Mexican forests is greatly affected by social issues such as land tenure and widespread poverty. At the same time, for $20 \%$ of the communities that own forest land, forest utilization is the central economic activity [1]. Forest utilization has been identified as a major factor that could positively affect the national economy, social inclusion and sustainable resource management [2].

Out of the 62.2 million hectares of total forest coverage in Mexico, half of the area is covered by rainforest and a quarter of the area of temperate forest is located in indigenous rural territories [3]. "Thanks to the presence of forest, this population addresses many of their subsistence needs which are not adequately internalized by the national economy" [3]. The link between low socioeconomic development and insufficient local resource management highlights the importance of forest utilization and sustainable management for the development of this sector. The integration of forest management and forest utilization on a sustainable basis fosters the creation of supply chains, which contribute to the improvement of the socioeconomic conditions of the local population.

Across the country, only a few communities have developed good practices for forest management (only 792,275 hectares certified as sustainable community forest management areas by the Forest 
Stewardship Council (FSC), representing $1.20 \%$ of the total national forested areas [4]). This is mainly due to the limited infrastructure of roads, low mechanization level of operations, poor transportation systems and social barriers that hinder efficient and profitable processes. Furthermore, most of the forest activities only offer short-term employment, which is performed by low qualified personnel. From the felling and extraction of timber to its transportation, forestry activities are often conducted with insufficient and inadequate equipment resulting in significant environmental impacts and high operating costs. In terms of economics, the forest financial situation in Mexico lacks funding opportunities, particularly because it is perceived as a high-risk investment. In addition, there is a little cooperation between the actors and stakeholders involved in the value chain, which results in a low-income flow in the long term.

In order to improve this situation, governmental initiatives have incorporated "Payment for Environmental Services" as monetary transactions to forest owners. The objective is to provide economic resources for the local conservation, protection and sustainable management of forests. Nevertheless, no financial support is provided for improving the efficiency of wood supply.

Not only are forests important for the economy and local communities, but biomass use in Mexico also presents a great opportunity for the production of electricity with a low environmental impact [5]. By the end of 2012, the installed capacity for electricity production using biomass was approximately 677.8 MW, with $89.6 \%$ from direct combustion of bagasse and $6.6 \%$ from biogas produced from residential, agricultural-livestock, industrial and urban solid waste. The remaining 3.8\% comes from the black liquor produced by the paper industry [6]. Furthermore, by the end of 2013 there were 66 bioenergy power plants in Mexico representing significant progress for the biomass utilization [6]. Nevertheless none of these projects integrated forest woody biomass in the energy supply chain. Bioenergy in Mexico seems to offer a great potential as a transition strategy for introducing new energy supply chains, especially to meet energy requirements of remote communities. According to the Energy Secretariat [5] by 2026 the bioenergy generation is expected to increase to $746 \mathrm{MW}$, which will represent a significant contribution to the diversification of the energy mix. In this context, several studies on the availability of woody biomass have been conducted. These investigations focused mainly on the introduction of new technology, innovating engineering requirements based on Mexican standards. However, there have been no studies that focus on the integration of wood supply chains for bioenergy generation within a framework of sustainability. Hence, this study focuses on advancing research for sustainable energy generation based on forest woody biomass in Mexico. The main objective is to develop and to apply a methodology for holistically evaluating the sustainable potential of supplying energy from decentralized bioenergy plants using woody biomass. With this method the available technical potential of woody biomass and the feasibility of its supply are analyzed to prove the hypothesis that, within the Mexican forest sector, there is significant sustainable potential for decentralized energy generation based on woody biomass that would improve the standard of living within the Mexican rural sector.

\section{Results}

Results are presented according to the three research modules for the three sources involving the theoretical, technical and economic potential of forest woody biomass for energetic use. Based on the national statistical yearbook from 2013 [7], production values were used to calculate the left on site residues coming from harvesting activities, applying the coefficients presented. The yearly harvested biomass residues from 1993 to 2013 are illustrated in Figure 1 by species and region. There is a difference between the residues left on site from pine and oak according to region, mainly caused by differences in total volume harvested, mechanization and technology development. Fir utilization is not carried out in the north, while oak, with an underdeveloped market, is relatively underutilized. Furthermore, pine utilization is intensive in the north, resulting in the highest amount of biomass residues from harvesting when compared to the central south. According to data observed along the time series, there is an opportunity for improving the conditions of the forest sector by keeping production levels close to the peak observed in 2007. Peaks observed in past years, 1998 and 2000 for 
instance, are a consequence of atypical fires and storms as unusual conditions. Year 2007, as last peak of the analyzed time series and based on typical conditions, is considered a benchmark for improvements.

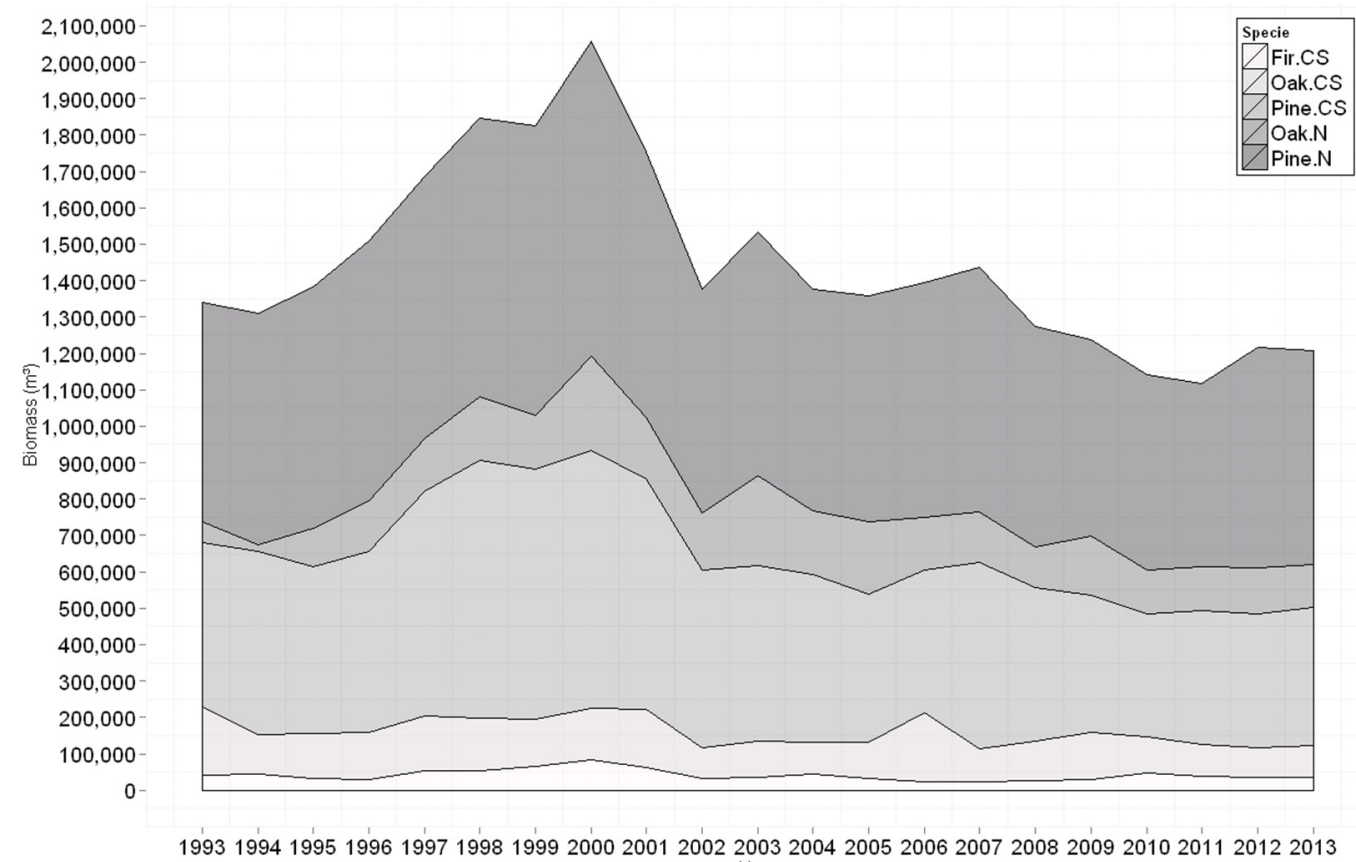

Figure 1. Theoretically available biomass residues $\left(\mathrm{m}^{3}\right)$ from harvesting for north and central-south regions by species (1993-2013).

\subsection{Availability and Appropriateness of Lignocellulose Biomass}

Taking into account year 2013 and a total timber production from the analyzed species of 2,917,696 $\mathrm{m}^{3}$ [7], the total additionally available theoretical biomass for energetic use from harvesting activities in the north region is $707,843 \mathrm{~m}^{3}$. Unlike the north, the central south region utilizes fir with a total of $501,215 \mathrm{~m}^{3}$ left on site biomass from harvesting. In order to account for the theoretically available biomass residues from non-extracted stands, Equation (2) (see Materials and Methods) is applied to this figure, resulting in 186,899 $\mathrm{m}^{3}$. Based on Equation (3), the theoretically available volume of sawmill residues by species and regions are derived. In 2013, round wood timber imports amounted to $8,071,420 \mathrm{~m}^{3}$ for sawmills [8]. When multiplying this value by the 0.41 sawmill residue coefficient, there is a total of $3,319,775 \mathrm{~m}^{3}$ theoretically available biomass for energetic use from sawmill residues. The status quo analysis indicates that the theoretical potential of available biomass for energetic use is $6,357,482 \mathrm{~m}^{3}$, where residues out of harvesting correspond to $19 \%$, non-extracted stands residues $3 \%$ and sawmill residues $78 \%$. Table 1 summarizes the availability of lignocellulose biomass for energetic use by species, region and source in order to present the theoretical potential as part of the first research module of the proposed methodology.

Figure 2 graphically summarizes the theoretical availability of woody biomass by source and species. The bars are divided by region where low bars, which have a smaller share of available biomass for energetic use, correspond to the central south region. For biomass coming from harvesting residues, pine has the highest value with $590,570 \mathrm{~m}^{3}$. The values $914,119 \mathrm{~m}^{3}$ and $65,619 \mathrm{~m}^{3}$ in the Table 1 correspond to pine coming out of sawmill residues and non-extracted stands residues, respectively. In all cases, the theoretical potential of woody biomass availability is higher in the north. Figure 2 only considers national production. 
Table 1. Theoretical availability of woody biomass from harvesting residues, non-extracted volume and sawmill residues by species and region for $2013\left(\mathrm{~m}^{3}\right)$.

\begin{tabular}{ccccc}
\hline Source & Pine & Oak & Fir & Total \\
\hline Harvesting Residues $\left(\mathrm{m}^{3}\right)$ & & & & \\
$\quad$ North & 590,570 & 117,273 & - & 707,843 \\
Central-south & 379,324 & 85,855 & 36,036 & 501,215 \\
$\quad$ Total & 969,894 & 203,128 & 36,036 & $1,209,058$ \\
Non-Extracted Stands $\left(\mathrm{m}^{3}\right)$ & & & & \\
$\quad$ North & 65,619 & 43,375 & - & 108,994 \\
Central-south & 42,147 & 31,755 & 4,004 & 77,906 \\
$\quad$ Total & 107,766 & 75,129 & 4,004 & 186,899 \\
Sawmill Residues $\left(\mathrm{m}^{3}\right)$ & & & & \\
$\quad$ North & 914,119 & 49,000 & - & 963,120 \\
Central-south & 587,140 & 35,874 & 55,618 & 678,631 \\
Imports & & & & $3,319,775$ \\
Total & $1,501,259$ & 84,874 & 55,618 & $4,961,526$ \\
TOTAL & & & & $6,357,482$ \\
\hline
\end{tabular}

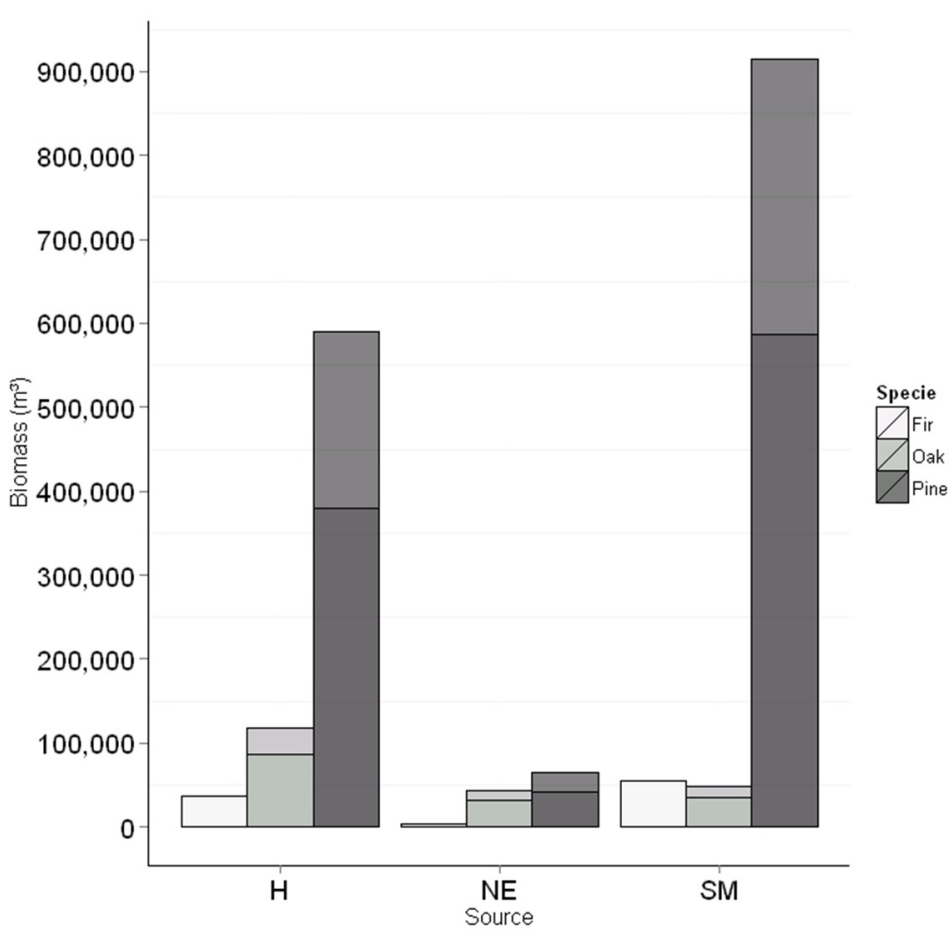

Figure 2. Theoretical availability of nationally produced woody biomass by source, species and region. Notes: $\mathrm{H}$ refers to woody biomass residues from harvesting, $\mathrm{NE}$ is the woody biomass residues from non-extracted stands and SM comprises woody biomass from sawmills. The bars are divided by region where low bars, which have a smaller share of available biomass for energetic use, correspond to the central south region.

\subsection{Forest Management for Bionergy Supply}

Using the factors developed and presented in Table 2, the technically available biomass for each region is calculated based on harvesting residues and constrained by soil degradation. This results in $486,494 \mathrm{~m}^{3}$ out of $707,843 \mathrm{~m}^{3}$ from the north and $344,480 \mathrm{~m}^{3}$ out of $501,215 \mathrm{~m}^{3}$ from the central south. The theoretically available biomass from harvesting residues was totaled for this analysis. 
Table 2. Biomass extraction factors according to soil degradation and degree.

\begin{tabular}{cccc}
\hline Degradation & Slight & Moderate & Severe \\
\hline Chemical & 0.677 & 0.010 & 0.000 \\
Physical & 0.696 & 0.001 & 0.000 \\
\hline
\end{tabular}

Then, based on GIS analyses, slope constraints together with soil degradation constraints were applied to the theoretical available biomass from non-extracted stands. The results presented in Table 3 show the distribution of this biomass according to slope class.

When only considering areas with a slope up to $35 \%$ and extraction limits based on soil degradation, the technical biomass availability from non-extracted residues is $45,982 \mathrm{~m}^{3}$ for the northern region and $32,921 \mathrm{~m}^{3}$ for the central southern region. These results are based on the biomass extraction factors from Table 2 and the biomass availability per slope class from Table 3. Furthermore, extraction limits restricted by mechanization level were developed using a rate between base line $(B L)$ productivities and the productivity required to harvest the amount of biomass from non-extracted stands constrained by slope percentage (see Table 4) within a production schedule of 7 months. This calculation assumes a power-saw team consisting of three men: a feller, an assistant and a helper [9].

Table 3. Technically available woody biomass from non-extracted stands constrained by slope percentage $\left(\mathrm{m}^{3}\right)$.

\begin{tabular}{ccccc}
\hline Region & \multicolumn{4}{c}{ Slope Class (\%) } \\
\hline North & $\mathbf{1 1 - 2 0}$ & $\mathbf{2 1 - 3 5}$ & $\mathbf{3 6 - 5 0}$ & $>\mathbf{5 0}$ \\
Pine & 112,404 & 111,369 & 74,105 & 66,672 \\
Oak & 38,211 & 37,860 & 25,192 & 22,665 \\
\hline Central-south & & & \\
Pine & 67,322 & 76,642 & 51,924 & 38,261 \\
Oak & 26,086 & 29,697 & 20,119 & 14,825 \\
Fir & 6059 & 6898 & 4673 & 3444 \\
\hline
\end{tabular}

Table 4. Productivities for manual felling using chainsaw according to species, slope class, Diameter at Breast Height $(D B H)$ and $D$ factor $\left(\mathrm{m}^{3} / \mathrm{h}\right)$

\begin{tabular}{ccccccc}
\hline \multirow{2}{*}{ Species } & \multirow{2}{*}{ Slope (\%) } & \multicolumn{5}{c}{ Diameter at Breast Height $(\mathbf{D B H})(\mathbf{c m})$} \\
\cline { 3 - 7 } & & $\mathbf{3 0}$ & $\mathbf{3 5 ( B \boldsymbol { L } )}$ & $\mathbf{4 0}$ & $\mathbf{4 5}$ & $\mathbf{5 0}$ \\
\hline Pine & \multirow{2}{*}{20} & 2.38 & 3.23 & 4.09 & 4.95 & 5.81 \\
Oak & 2.78 & 3.78 & 4.79 & 5.79 & 6.80 \\
Fir & & 2.40 & 3.27 & 4.13 & 5.00 & 5.87 \\
Pine & & 1.93 & 2.63 & 3.32 & 4.02 & 4.72 \\
Oak & \multirow{2}{*}{35} & 2.26 & 3.07 & 3.89 & 4.71 & 5.52 \\
Fir & & 1.95 & 2.65 & 3.36 & 4.06 & 4.77 \\
Pine & & 1.49 & 2.02 & 2.56 & 3.09 & 3.63 \\
Oak & \multirow{2}{*}{50} & 1.74 & 2.36 & 2.99 & 3.62 & 4.25 \\
Fir & & 1.50 & 2.04 & 2.58 & 3.12 & 3.67 \\
\hline
\end{tabular}

Taking into consideration the sustainability constraints (soil degradation, slope percentage and mechanization level) on harvesting residues and non-extracted stands residues, the technical potential for woody biomass for energetic use sums up to $830,930 \mathrm{~m}^{3}$ and $6,223 \mathrm{~m}^{3}$, respectively (see Table 5). 
Table 5. Technical availability of woody biomass for 2013 constrained by soil degradation, slope percentage and mechanization level $\left(\mathrm{m}^{3}\right)$.

\begin{tabular}{|c|c|c|c|c|}
\hline Source & Pine & Oak & Fir & Total \\
\hline \multicolumn{5}{|c|}{ Harvesting Residues $\left(\mathrm{m}^{3}\right)$} \\
\hline North & 405,893 & 80,600 & - & 486,494 \\
\hline Central-south & 260,706 & 59,007 & 24,767 & 344,480 \\
\hline Total & 666,599 & 139,608 & 24,767 & 830,973 \\
\hline \multicolumn{5}{|c|}{ Non-Extracted Stands $\left(\mathrm{m}^{3}\right)$} \\
\hline North & 812 & 1,847 & - & 2,659 \\
\hline Central-south & 821 & 1,868 & 875 & 3,564 \\
\hline Total & 1,633 & 3,715 & 875 & 6,223 \\
\hline \multicolumn{5}{|c|}{ Sawmill Residues $\left(\mathrm{m}^{3}\right)$} \\
\hline North & 914,119 & 49,000 & - & 963,120 \\
\hline Central-south & 587,140 & 35,873 & 55,618 & 678,631 \\
\hline Imports & & & & $3,319,775$ \\
\hline Total & $1,501,259$ & 84,874 & 55,618 & $4,961,526$ \\
\hline TOTAL & & & & $5,798,722$ \\
\hline
\end{tabular}

Estimation of Costs Associated with Utilizing Available Woody Biomass for Energetic Use

Monte Carlo simulations were carried out for each cost involved in utilizing the resulting available woody biomass for energetic use. For the northern region, the costs for utilizing the harvesting residues were simulated according to 7,852 iterations. A total of 8,242 iterations for the cost of utilizing the non-extracted stand residues were carried out. 10,784 iterations for the costs associated with utilizing sawmill residues were run. All simulations had 100 repetitions. Tables 6 and 7 show the statistic parameters for each cost by region. Based on the official exchange rate on December 31, 2013: 1.00 USD (United States Dollar) = 13.06 MXN (Mexican Peso) [10]).

Table 6. Monte Carlo simulation results according to cost for the northern region.

\begin{tabular}{cccc}
\hline \multirow{2}{*}{ Parameter } & \multicolumn{3}{c}{ Cost $\left(\mathbf{M X N} / \mathbf{m}^{\mathbf{3}}\right)$} \\
\cline { 2 - 4 } & Harvesting residues & Non-extracted stands residues & Sawmill residues \\
\hline Min & 150.34 & 196.82 & 98.47 \\
Max & 759.49 & 852.33 & 526.10 \\
Mean & $\mathbf{4 4 5 . 6 3}$ & $\mathbf{5 2 9 . 7 1}$ & $\mathbf{3 1 2 . 2 9}$ \\
Standard dev. & 106.93 & 111.06 & 89.48 \\
Confidence interval of 95\% & $443.26 \leq \mathrm{X} \leq 447.99$ & $527.31 \leq \mathrm{X} \leq 532.11$ & $310.60 \leq \mathrm{X} \leq 313.98$ \\
Range & 609.15 & 655.50 & 427.63 \\
Standard error & $0.81 \%$ & $0.69 \%$ & $0.83 \%$ \\
Number of simulations (N) & 7,852 & 8,242 & 10,784 \\
\hline
\end{tabular}

Table 7. Monte Carlo simulation results according to cost for the central south region.

\begin{tabular}{cccc}
\hline \multirow{2}{*}{ Parameter } & \multicolumn{3}{c}{ Cost $\left(\mathbf{M X N} / \mathbf{m}^{\mathbf{3}}\right)$} \\
\cline { 2 - 4 } & Harvesting Residues & Non-Extracted Stands Residues & Sawmill Residues \\
\hline Min & 82.42 & 109.11 & 132.51 \\
Max & $1,552.94$ & $1,808.46$ & 895.17 \\
Mean & $\mathbf{8 1 4 . 6 8}$ & $\mathbf{9 7 8 . 7 4}$ & $\mathbf{5 8 2 . 7 6}$ \\
Standard dev. & 240.07 & 250.55 & 163.29 \\
Confidence interval of 95\% & $811.09 \leq \mathrm{X} \leq 818.26$ & $975.07 \leq \mathrm{X} \leq 982.41$ & $580.16 \leq \mathrm{X} \leq 585.37$ \\
Range & $1,470.52$ & $1,699.34$ & 762.65 \\
Standard error & $0.67 \%$ & $0.37 \%$ & $0.44 \%$ \\
Number of simulations $(\mathrm{N})$ & 17,232 & 17,900 & 15,096 \\
\hline
\end{tabular}


For the north, results show a total cost of $445.63 \mathrm{MXN} / \mathrm{m}^{3}\left(34.12 \mathrm{USD} / \mathrm{m}^{3}\right)$ for utilizing harvesting residues, $529.71 \mathrm{MXN} / \mathrm{m}^{3}\left(40.55 \mathrm{USD} / \mathrm{m}^{3}\right)$ for non-extracted stands residues and $312.29 \mathrm{MXN} / \mathrm{m}^{3}$ $\left(23.91 \mathrm{USD} / \mathrm{m}^{3}\right)$ for sawmill residues. Using a triangular probabilistic function for transportation costs within the central south region, the harvesting costs summed $814.68 \mathrm{MXN} / \mathrm{m}^{3}\left(62.37 \mathrm{USD} / \mathrm{m}^{3}\right)$ while the cost for utilizing non-extracted stand residues amounted to $978.74 \mathrm{MXN} / \mathrm{m}^{3}\left(74.94 \mathrm{USD} / \mathrm{m}^{3}\right)$. The utilization cost for sawmill residues resulted in $582.76 \mathrm{MXN} / \mathrm{m}^{3}\left(44.62 \mathrm{USD} / \mathrm{m}^{3}\right)$.

Again, as shown by the cost estimation based on averages from samples, all the costs are higher in the central south region, with the exception of road construction and maintenance cost. Values are affected by the number of samples taken by region affecting the variability explained in the next section.

\subsection{Energy Output}

Forest woody biomass production and utilization for energetic use per selected sources is analyzed in a biomass energy flow chart. Figure 3 presents this chart, which is based on theoretically available biomass that was estimated using data from the first research module. Energy values associated to each product are calculated and shown in the flow chart. With the chart it is possible to trace biomass production and end-use, including energy content per cubic meter. Only the national production from the analyzed sources is taken into account; imports are excluded.

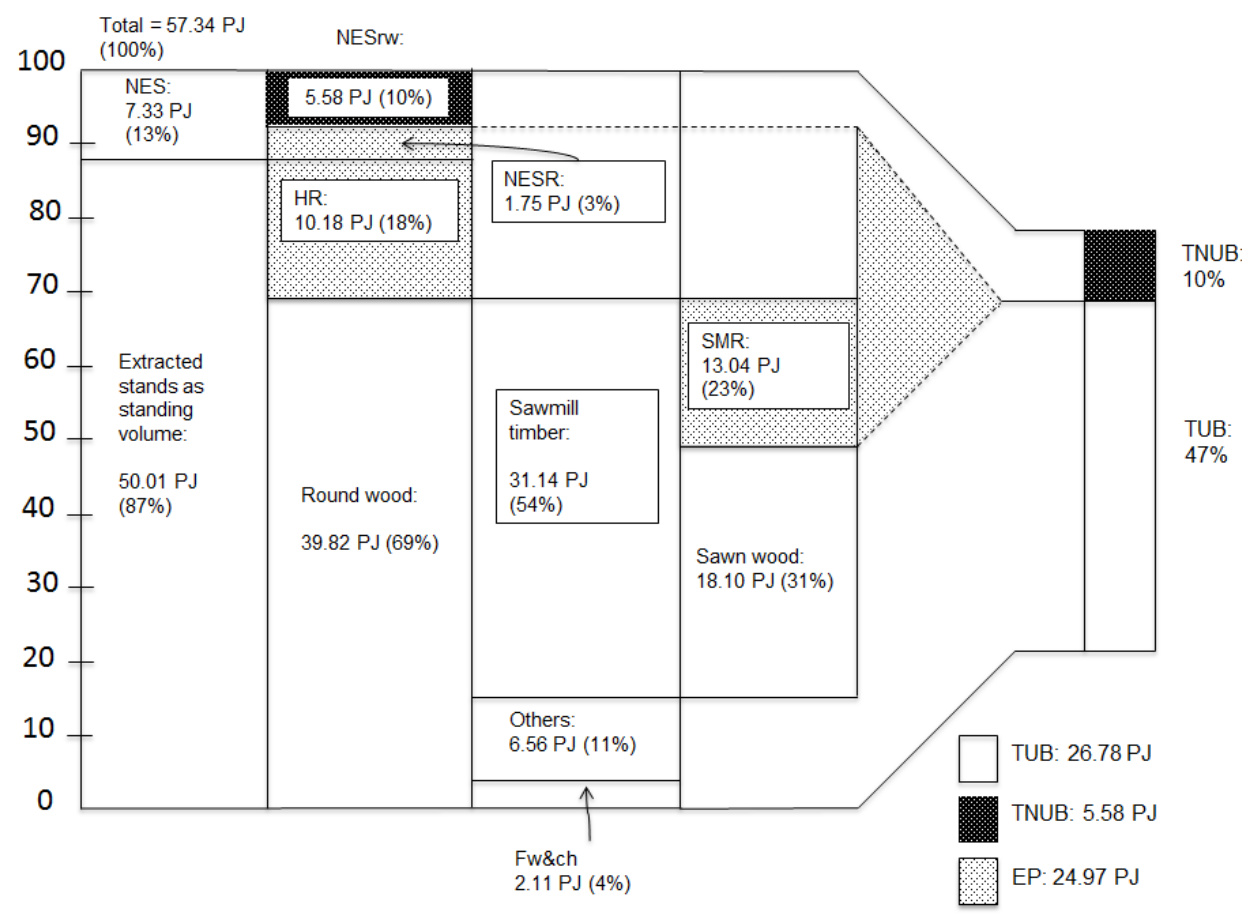

Figure 3. Biomass energy flow chart for the regional case study based on 10 provinces involving analyzed species and sources. Notes: TUB: Refers to the theoretically available energy from utilized forest woody biomass. TNUB: The total theoretically available energy from non-utilized forest woody biomass. EP: Represents the theoretical energy potential from harvesting residues, non-extracted stands and sawmill residues. NES: Theoretically available energy from non-extracted stands. NESrw: Theoretically available energy from non-extracted stand in the form of round wood. Fw\&ch: Theoretically available energy from round wood production in the form of firewood and charcoal. HR: Theoretically available energy from harvesting residues. NESR: Theoretically available energy from non-extracted stands residues. SMR: Theoretically available energy from sawmill residues.

After reviewing the theoretical energy potential with the biomass energy flow chart, estimates of the technical energy potential are calculated. For the woody biomass for energetic use presented in the last research module, the technical forest woody biomass for energetic use totals $5,798,722 \mathrm{~m}^{3}$. This is 
comprised of 1,056,542 tons of pine, 168,865 tons of oak and 30,979 tons of fir (see Table 8). These results show an available technical potential of 45.96 PJ for 2013 from the analyzed sources.

Table 8. Technically available forest woody biomass for energetic use (ton)

\begin{tabular}{ccccc}
\hline Region & Pine & Oak & Fir & Total \\
\hline North & 628,007 & 92,239 & 0 & 720,246 \\
Central-south & 413,300 & 71,594 & 30,879 & 515,773 \\
Sawmill imports & & & & $1,616,730$ \\
TOTAL & $1,056,542$ & 168,865 & 30,979 & $2,873,016$ \\
\hline
\end{tabular}

Table 9 presents a breakdown of energy values divided by region, species and source. It should be noted that this potential only considers the $15.1 \%$ of the total national forested area that is under management [11].

Table 9. Technically available energy from forest woody biomass (PJ)

\begin{tabular}{ccccc}
\hline Region & Pine & Oak & Fir & Total \\
\hline North & 10.29 & 1.56 & - & 11.85 \\
Central-south & 6.61 & 1.14 & 0.49 & 8.25 \\
Sawmill imports & & & & 25.86 \\
TOTAL & 16.90 & 2.70 & 0.49 & 45.96 \\
\hline
\end{tabular}

\section{Discussion}

Mexico is one of the 15 countries with the largest area of primary forest worldwide [12]. According to the National Forestry Council (Comision Nacional Forestal) Mexico has a forested area of approximate 62 million hectares, amounting to $47 \%$ of the national vegetation surface. These national forest areas are inhabited by 12 million people who are affected by extreme poverty and migration [13]. The local population faces difficulties in efficiently and effectively utilizing the forest resources due to low support for sustainable forest management, such as programs for capacity development.

Regarding energy supply, the main source for rural people throughout the country is firewood, however this resource is not managed sustainably. Within industrial production, the utilization of energy wood along with the traditional industrial wood has not been yet pursued. In 2014, biomass accounted for $4.1 \%$ of the primary energy demand in Mexico, mainly for firewood in households and small industries, as well as sugar cane bagasse from sugar mills [14].

On the other hand, over the years, fluctuations in timber production have been a result of political priorities and market developments. Since 2001, for example, an increase in national timber demand has affected the commercial and industrial balance. In 2004 only $39 \%$ of the national timber demand was met with national production [8] and in 2007 Mexico imported 4.3 million $\mathrm{m}^{3}$ of softwood coming mainly from Chile (35\%) and the United States (23\%) [15]. In 2013, approximately $71 \%$ of the national timber consumption was being imported [7], resulting in significant opportunities for the development of regional clusters that lead the sector towards a sustainable and profitable industry.

In order to develop the forest sector in Mexico, its economic profitability must be strengthened. This could be achieved through the application of programs, to be guided by the implementation of policies for market development and integration of the stakeholders involved in the value chain. This would allow for the diversification of products, with energy being one such example. Moreover, developing a bioenergy market based on forest woody biomass involves several challenges regarding forest management, forest operations, logistics and stakeholders' integration. The conjunction of aspects based on proper technology and sustainable forest management is significant for the creation of efficient energy supply chains that enables the development of a woody market in Mexico. Thus, in order to face the low integration of the Mexican forest value chain, the following points 
suggest general steps for developing the sector and therefore introducing a market: (1) Throughout capacity development and cooperation between authorities and stakeholders within the value chain, overcoming the technological backwardness of the forest industry is fundamental; (2) As a key parameter of forest logistics, improving the infrastructure of forest roads must be met; (3) General meetings, symposium and congresses must be critical for achieving an integration of the forest sector; (4) Ensuring competitiveness of forest enterprises will boost the market; (5) Improving integration of research, academy and forest's sector needs must be considered, together with research and technology development. The introduction of a robust bioenergy market relies in conducting analyses on wood resources access, harvesting operations, silvicultural practices and business models.

Bioenergy analyses conducted in Mexico suggest opportunities for the development of bioenergy supply chains. Based on moderate and high scenarios, Islas et al. [16] presents a technical potential for 2004 of $71 \mathrm{PJ} /$ year from sawmill residues and harvesting residues, 997-1791 PJ/year from natural forest and 450-1246 PJ/year from plantations. Moreover, García et al. [17] calculates an energy potential of $64 \mathrm{PJ} /$ year from wood pellets burned for heat and $108 \mathrm{PJ} /$ year from traditional wood-fuel for efficient cook stoves. In a further study, Rios and Kaltschmitt [18] point to a bioenergy potential of 638 PJ from forest and shrub woody biomass residues and 26 PJ from woody industry residues for the year 2010. Unlike these studies, the methodology developed in this research considers forest management criteria as sustainability constraints based on extraction limits. That is to say, it takes into consideration harvesting and transporting constraints to estimate technically available biomass for energetic use, including estimations of productivities according to equipment and mechanization level.

The introduction of new forest operations techniques within the Mexican forest sector could positively impact these extraction limits, allowing the utilization of additional technically available woody biomass for energetic use. For instance, the introduction of advanced extraction, loading and transportation techniques, could decrease soil degradation, resulting in a higher woody biomass utilization potential. Another example of a system that could extend extraction limits that are constrained by soil degradation is cable yarding, which is a transportation system of logs from the stump area to the roadside mainly for swampy, steep or very broken ground [9]. The application of cable yarding systems may result in lower surface disturbance and very low compaction [9]. When modeling lower surface degradation achieved through the introduction of advance techniques in forest operations, such as cable yarding systems, and assuming a conservative increment of $20 \%$ on the maximum extraction rates for moderate and severe degradation, the potential of woody biomass for energetic has an increment of $8,740 \mathrm{~m}^{3}$. Additionally, such systems allow log extraction at steep conditions. With its considerable effect on the mechanization level and the possibility to access biomass on slopes beyond $35 \%$, cable yarding produces an additional $321,881 \mathrm{~m}^{3}$ in the modeling results of available biomass to be utilized for energetic uses.

These results are calculated within a status quo scenario, meaning that only $15.1 \%$ of the total forest area is being utilized [11]. Therefore, assessments assuming an increase of managed forest areas and its consequences within a time frame, involving future scenario analysis for the calculation of sustainable potential, can be addressed using the proposed methodology. With such an assessment, it is possible, for example, to analyze the weight sawmill timber imports have over a period of time, enabling recommendations based on the modeling of scenarios. When a larger forest area can be sustainably utilized, the dependency on sawmill timber imports will be reduced and the further effects related to forest operations and bioenergy supply will boost the Mexican forest sector. Moreover, the analyzed regional case study focuses only in pine, oak and fir. Nevertheless, assessments using other species, as well as an increase of hectares based on plantation forestry supported by short rotation species, can be performed with the developed model.

The introduction of bioenergy supply chains based on woody biomass leads to the creation of jobs along the value chain. For instance, when analyzing the number of teams needed to harvest the total available biomass per slope class, there is a potential of 152 power-saw teams (a power-saw team is assumed to consist of three workers). Modeling parameters on species, hectares under sustainable 
utilization, soil degradation and mechanization level over a period of time can have repercussions on decision making regarding forestry and bioenergy supply chains based on woody biomass in Mexico.

The estimated 45.96 PJ represents an energy increment of $12 \%$ according to the current $363.28 \mathrm{PJ}$ of bioenergy production at a national scale [14]. Again, this potential is calculated with the 8.6 million hectares under forest management, which is only $15.1 \%$ of the total forested areas [11]. Assuming the size is increased to the 21.6 million hectares that have a potential for production [11], the availability of forest woody biomass for energetic use will play an important role within the Mexican rural sector in terms of forest management and energy generation.

In regard to economics, the national forestry data from the last trimester of 2013 estimates a price of $773.50 \mathrm{MXN} / \mathrm{m}^{3}$ for free on board small $\log$ dimensions of pine in sawmills of the northern region. In the central south an average of $772.01 \mathrm{MXN} / \mathrm{m}^{3}$ is observed [19]. When comparing this against the estimated costs, $445.63 \mathrm{MXN} / \mathrm{m}^{3}$ and $814.68 \mathrm{MXN} / \mathrm{m}^{3}$ for harvesting residues for each region, there is a positive profit margin in the northern region. Cost could be lowered in central south region, by integrating the transportation and extracting activities, including approaches on production scheduling and adaptation of engineering methodologies as just in time (JIT) for example.

Concerning addressing local energy requirements, Sanchez Peña [20] conducted research on the energy consumption per capita of rural and urban Mexican households. Using data from the "Encuesta Nacional del Ingreso-Gasto de los Hogares" (National Survey of Income-Expenditures of Households or ENIGH) on fuel expenditure of households, the research correlated the residential energy expenditure (\$), the average fuel prices (\$) and net heating values (MJ). A variable of residential energy consumption was obtained out of this analysis. According to Sanchez Peña, the energy consumption per capita of households on the rural sector is 1,194.6 MJ per trimester. A correlation between the income and the sector resulted in residential energy consumptions for the rural sector with poor income and low income of 772.4 MJ and 1,297.3 MJ per trimester, respectively [20]. This means that approximately 59,049,715 poor income households or 35,157,635 low income households could satisfy their energy needs with the estimated available woody biomass of 2.9 million tons per year.

The introduction of energy supply chains based on local resources is relevant for the development of rural communities, where one of the most important energy products national wide is firewood. Furthermore, there is a potential for the Mexican forest sector in carbon mitigation strategies, biodiversity co-benefits [21], bioenergy generation and job creation. It is important for further research to analyze the potential development of the Mexican forest sector in terms of operations and logistics in order to identify feasible bioenergy supply chain based on forest woody biomass.

\section{Materials and Methods}

The research is based on a biomass availability analysis that includes an assessment of the quality and quantity of lignocellulose biomass residues for energetic use. Harvesting operations are studied in order to analyze and evaluate scenarios for bioenergy supply based on cost, mechanization level, soil degradation and slope percentage. Based on the correlation of research modules, the study will, finally, integrate an analysis of the theoretical, technical and economic feasibility towards an assessment of the sustainable energy output. These research modules are:

i. Availability and appropriateness of lignocellulose biomass: This focuses on estimating the theoretical potential of woody biomass for energetic use, excluding natural protected areas. Within the module, biomass availability refers to the potential of woody biomass for bioenergy generation without considering sustainability constraints. This research module involves the development of equations and coefficients in order to carry out numerical modeling based on historical data analysis.

ii. Forest management for bioenergy supply: This includes an evaluation of mechanization level, soil degradation and slope percentage as sustainability constraints. Extraction limits restrict the amount of available woody biomass. In addition, harvesting operations are reviewed for the mechanization level assessment. Inventory data, numerical modeling and GIS analyses are used 
for developing equations according to sustainability constraints. Moreover, this research module contains Monte Carlo analyses that estimates costs associated with utilizing the available woody biomass for energetic use.

iii. Energy output: Using net heating values according to moisture content, this module analyses the amount of available energy after sustainability constraints have been applied. A biomass energy flow chart is presented, which includes energy values for each analyzed source and species.

As part of the analysis, a spatial approach based on two regions is carried out. This involves 10 provinces comprising areas with the highest timber production at national scale: The northern region includes the provinces of Durango and Chihuahua, while the central-south is represented by Michoacán, Oaxaca, Puebla, Veracruz, Chiapas, Guerrero, Jalisco and the state of Mexico. Differences regarding forestry at a regional scale are shown in Table 10, based on information from the National Institute of Statistics and Geography [22], and the two documents "Diagnóstico de las capacidades y situación tecnológica del sector forestal y forestal industrial del país" (Diagnostic of the capabilities and technology situation of the forest sector and forest industry in the country) [23] and "Competitividad y Acceso a Mercados de Empresas Forestales Comunitarias en México" (Competitiveness and market access of community forest enterprises in Mexico) [24].

Table 10. Differences in forestry parameters according to region.

\begin{tabular}{ccccccc}
\hline Region & $\begin{array}{c}\text { Round Wood } \\
\text { Production } \\
\left(\mathbf{m}^{3}\right)\end{array}$ & $\begin{array}{c}\text { Sawmill } \\
\text { Production } \\
\left(\mathbf{( m}^{3}\right)\end{array}$ & $\begin{array}{c}\text { Average Mean } \\
\text { Annual } \\
\text { increment } \\
\left(\mathbf{m}^{3} / \mathbf{y e a r}\right)\end{array}$ & $\begin{array}{c}\text { Average } \\
\text { Area under } \\
\text { Utilization } \\
(\mathbf{h a})\end{array}$ & $\begin{array}{c}\text { Total Forest } \\
\text { Area (ha) }\end{array}$ & $\begin{array}{c}\text { Average } \\
\text { Transportation } \\
\text { Distances } \\
\mathbf{( k m})\end{array}$ \\
\hline North & $2,917,696$ & $2,184,768$ & 2.04 & 134,917 & $9,778,680$ & 14 \\
Central-south & $2,217,803$ & $1,926,216$ & 3.40 & 9,716 & $6,127,962$ & 51 \\
\hline
\end{tabular}

The "average transportation distances" refers to distances between the loading point in the forest and final unloading point at a fictional power plant. As seen on the table, the northern region has a higher amount of forest areas as well as higher production of round wood and sawmill than the areas observed in the central southern region. Data on averages may vary due to the sampled universe within each study.

The analysis focuses on the use of three tree species pine, oak and fir. Table 11 presents four variable sets, which are modeled to assess the outlined potentials. Because limited data and data access to parameters which are fundamental inputs of the model, results are based on a status quo analysis set for the year 2013, considering three sources:

(1). Woody biomass residues from harvesting: It includes woody biomass that was left on side after harvesting operations, including badly shaped logs, logs not reaching the standard diameter for transformation (between $2.5 \mathrm{~cm}$ and $12.5 \mathrm{~cm} \mathrm{DBH}$ ) and branches with no commercial use.

(2). Woody biomass residues from non-extracted stands: These are remaining stands that were marked for utilization but were not harvested according to the management plan.

(3). Woody biomass residues from sawmills: This refers to wood pieces with no commercial use after sawmill processing, in the form of cuts, strips and sawdust.

As already mentioned, these sources include private and communal forest, excluding natural protected areas. In order to have accurate results for the status quo analysis, this study only considers the forested areas under management. Therefore, calculations are based on the timber production of forest lands under management. 
Table 11. Variable sets of research methodology.

\begin{tabular}{|c|c|c|c|}
\hline Variable Set One & Variable Set Two & Variable Set Three & Variable Set Four \\
\hline 1. Forest productive area (ha) & 1. Soil degradation (\%) & $\begin{array}{l}\text { 1. Heating value } \\
\text { (lower) }(\mathrm{kJ} / \mathrm{kg})\end{array}$ & $\begin{array}{l}\text { 1. Labor cost for harvesting } \\
\text { and extraction (\$) }\end{array}$ \\
\hline 2. Available tree species & 2. Terrain slope $(\%)$ & 2. Energy demand (PJ) & $\begin{array}{l}\text { 2. Labor cost for machine } \\
\text { operation }(\$)\end{array}$ \\
\hline $\begin{array}{l}\text { 3. Average annual increment } \\
\left(\mathrm{m}^{3} / \text { year }\right) \\
\text { 4. Production }\left(\mathrm{m}^{3} / \text { year }\right) \\
\text { 5. Basic wood density }\left(\mathrm{kg} / \mathrm{m}^{3}\right) \\
\text { 6. Round wood production for } \\
\text { sawmills }\left(\mathrm{m}^{3} / \text { year) }\right.\end{array}$ & 3. Mechanization level (\%) & & $\begin{array}{l}\text { 3. Road construction and } \\
\text { maintenance cost }(\$) \\
\text { 4. Transportation cost }(\$) \\
\text { 5. Technical support cost }(\$)\end{array}$ \\
\hline
\end{tabular}

Numerical modeling is carried out by developing equations for estimating biomass availability, as well as extraction limits according to sustainability constraints. These constraints are:

i. Slope percentage: It constrains biomass availability according to forested areas on up to $35 \%$ slope. GIS spatial analyses are carried out to determine extraction limits.

ii. Soil degradation: Physical and chemical soil degradation are assessed, represented by compaction and soil fertility. Equations to account for extraction limits are developed using inventory data and numerical modeling. In addition, historical data on the land use in each province is analyzed.

iii. Mechanization level: It covers a productivity assessment of harvesting operations given equipment, slope percentage at felling site and diameter at breast height $(D B H)$ of the stand to be felled. The harvesting cycle includes felling, debranching and bucking. The rate between the calculated base line productivity and the productivity required to utilize the theoretically available woody biomass is set as extraction limit.

\subsection{Research Design}

The methodology of this research comprises of an assessment of the theoretical, technical and economic potential of woody biomass availability for energetic use. It incorporates forest management criteria as sustainability constraints for calculating the sustainable potential. This is represented by an assessment of the mechanization level on harvesting and transportation that impact woody biomass availability within a time frame. The methodology uses statistical, geographical and historical data from official reports as input to obtain the potentials. The core components according to the research design are described below:

(1) A spatial approach is carried out delimiting the geographical area for analysis with $i$ as the analyzed species out of a $n$ number of species in a $j$ region or site based on land use and inventory data

(2) At a theoretical and technical level, equations to account for the availability of woody biomass as well as extraction limit equations are developed for numerical modeling using coefficients from literature together with statistical and geographical data

(3) GIS spatial analysis involving digital elevation models (DEM) are used to analyze terrain conditions in order to calculate sustainability constraints

(4) For the economic potential, Monte Carlo simulations are developed in order to estimate production cost from utilization and transportation

(5) Based on the biomass theoretically available for energetic use, a biomass energy flow chart is presented for tracing biomass production involving source and end use. Energy values, and its percentage of the total production, are allocated for each source within the diagram

For the first research module, coefficients to estimate the theoretical availability of woody biomass for energetic use are identified. These are: 
- Coefficient from harvesting residues (C): It considers the amount of cut volume in cubic meters remaining after harvesting as residues on site. Values are estimated as rates of the total harvested volume

- Coefficient from non-extracted residues (Cne): It accounts for a rate of non-extracted stands of the total analyzed area as residues

- Coefficient from sawmill residues (Cs): It comprises of the available cubic meters as biomass residues from sawmill based on timber production

\subsubsection{Availability and Appropriateness of Lignocellulose Biomass}

An estimation of residues out of harvesting activities for both regions was developed using 0.18 for pine, 0.35 for oak and 0.19 for fir as residue coefficients from harvesting [25]. Basic densities were set to $0.487 \mathrm{t} / \mathrm{m}^{3}, 0.740 \mathrm{t} / \mathrm{m}^{3}$ and $0.380 \mathrm{t} / \mathrm{m}^{3}$ for pine, oak and fir respectively at $15 \%$ moisture content dry basis [26]. Equation (1) presents the relation between variables to calculate the theoretical available biomass residues from harvesting:

$$
H_{j}=\sum_{i=1}^{n} \frac{P_{i j}}{\left(1-C_{i}\right)} \times C_{i}
$$

where $H$ is the theoretical available biomass residues from harvesting $\left(\mathrm{m}^{3}\right), P$ is the utilized volume of the harvested timber $\left(\mathrm{m}^{3}\right), C$ is the coefficient from harvesting residues and $i$ is the analyzed species out of a $n$ number of species within a $j$ region.

In order to calculate the theoretical available biomass from non-extracted stands by region and species, the coefficients from non-extracted stand residues are set, using 0.10 for conifers and 0.27 for Quercus [25]. To obtain the non-extracted stands residues, Equation (2) is explained below:

$$
N E_{j}=\sum_{i=1}^{n}\left[\frac{\left(H_{i j}+P_{i j}\right) \times C n e_{i}}{1-C n e_{i}}\right] \times C_{i}
$$

where $N E$ is the non-extracted stands biomass residues $\left(\mathrm{m}^{3}\right), H$ is the theoretical available biomass residues from harvesting $\left(\mathrm{m}^{3}\right), P$ is the utilized volume of harvested timber $\left(\mathrm{m}^{3}\right), C$ is the coefficient from harvesting residues, $C n e$ is the coefficient of non-extracted stands residues and $i$ is the analyzed species out of a $n$ number of species within a $j$ region.

Taking into consideration the sawn wood volume from pine, oak and fir regardless of the region, the total of 4,205,321 $\mathrm{m}^{3}$ had share of $91 \%, 5 \%$ and $4 \%$ respectively. Due to the lack of information to classify this amount into north and central-south, percentages were allocated according to regions using data from national timber production of each species. The national timber production share of pine, oak and fir was calculated, based on information from the statistical yearbook of forestry production 2013. A residue biomass coefficient (Cs) of 0.41 was used for conifers. The sawmill residues volume for oak was calculated using 0.53 as coefficient (Cs) [25]. Calculations for estimating the theoretical available biomass for energetic use from sawmills are presented in Equation (3):

$$
S m_{j}=\sum_{i=1}^{n}\left[\frac{P_{i j}}{T_{i}} \times S w_{i}\right] * C s_{i}
$$

where $S m$ is the biomass theoretically available from sawmill residues $\left(\mathrm{m}^{3}\right), P$ is the utilized volume of harvested timber $\left(\mathrm{m}^{3}\right), T$ is the total national timber production $\left(\mathrm{m}^{3}\right), S w$ is the sawn wood production $\left(\mathrm{m}^{3}\right), C s$ is the coefficient from sawmills residues and $i$ is the analyzed species out of a $n$ number of species in a $j$ region.

Round wood imports were also taken into consideration using data from the national statistical yearbook of forest production from 2013 [7] and 0.41 as the sawmill residue coefficient [25]. This data was multiplied by the sawmill residue coefficient in order to have the amount of theoretical available 
biomass from sawmill residues. The sawmill residue coefficient for conifers was used for imports due to the high degree of softwood in sawmill production.

\subsubsection{Forest Management for Bioenergy Supply}

This research module is centered in the estimation of the technical potential of available biomass for energetic use constrained by soil degradation, slope condition and mechanization level based on the creation of extraction limits. The research module also presents an economic calculation for harvesting and transportation costs as a part of the economic potential of the analysis.

\section{Extraction Limit according to Soil Degradation}

An evaluation of the soil conditions in each region was carried out, focusing on chemical and physical degradation. Chemical degradation refers to fertility loss, pollution, salinization and eutrophication. Physical degradation considers compaction, crusting, flooding, reduction of water availability and loss of productivity. The National Ministry of Environment and Natural Resources (SEMARNAT) argues that the decrease in soil fertility is the first cause of chemical degradation within the country, having a share of $93 \%$ of the total affected areas. Moreover, compaction is the main reason for physical soil degradation affecting $68 \%$ of the degraded areas [27]. Therefore, the development of extraction limits is focused on these two variables: decrease of soil fertility and compaction.

The theoretically available biomass from harvesting was used to calculate the technical potential constrained by soil degradation. Soil degradation refers to processes induced by human activities that decrease biological productivity and its current or future capability to sustain human life [28]. Extraction limit factors were calculated setting slight, moderate and severe as protection measures to reduce degradation risks. Extraction limits were based on information collected in a literature review together with national inventory data and the "Evaluación de la degradación del suelo causada por el hombre en la República Mexicana" (Assessment of soil degradation caused by man in Mexico) [27]. The limits were set estimating the technical potential of available biomass for energetic use according to the values presented in the first research module. It is important to mention that the surface used in the "Assessment of soil degradation caused by man in Mexico" analysis does not include water areas, urban settlements, urban areas, areas without vegetation and insular areas. The extraction limits are presented for each region according to the mentioned scale. For this purpose, the percentage of degraded soil for the forest in each region was estimated using national-level data classified into slight, moderate and sever. In order to account the affected hectares by soil degradation in each province, the total forested area per province was then related to the previous calculated percentages, resulting in total degraded hectares by region. Because of limited information on soil degradation in specific areas, both physical and chemical, assumptions were made in order to have a regional approach. Based on data on physical and chemical degradation at a national scale in temperate and cloud forests together with the total forested surface for the north and central south regions, the amount of forest land with potential for soil degradation was estimated for use at province level. The forested areas affected by soil degradation at province level and classified into slight, moderate and severe were transformed into hectares affected by chemical and physical soil degradation by province. That is to say, the share of degraded forested areas at a province level was assumed to have a direct relation to the share of affected areas of temperate and cloud forests at a national scale. The sum of these province values resulted in the regional degraded hectares. In order to calculate the total chemical and physical degraded forested hectares by region and degradation degree, Equations (4)-(7) explain the calculations based on the relation between total forested area, areas affected by soil degradation at a national scale and soil degradation by vegetation type at a national scale.

$$
\text { Dslight }_{j}=\sum_{i=1}^{n} F a_{i} \times P S_{\text {slight }} \times S_{i j}
$$




$$
\begin{gathered}
\text { Dmoderate }_{j}=\sum_{i=1}^{n} F a_{i} \times P S_{\text {moderate }} \times S_{i j} \\
\text { Dsevere }_{j}=\sum_{i=1}^{n} F a_{i} \times P S_{\text {severe }} \times S_{i j} \\
D_{\text {tot }}=\sum_{i=1}^{n}\left(D_{\text {slight }}+D_{\text {moderate }}+D_{\text {severe }}\right)
\end{gathered}
$$

where $D_{\text {slight }}$ is the slightly degraded forest area (ha), $D_{\text {moderate }}$ is the moderately degraded forest area (ha), $D_{\text {severe }}$ is the severely degraded forest area (ha), $D_{\text {tot }}$ is the degraded forest area at a regional level (ha), $F a$ is the total forested area (ha), PS is the percentage of area affected by soil degradation in temperate and cloud forest at a national scale, $S$ is the soil degradation percentage (chemical or physical) in temperate and cloud forest at national scale, $n$ is the number of provinces involved in the analyzed region, $i$ refers to the current province being analyzed and $j$ is the type of soil degradation, either chemical or physical.

The forested areas affected by soil degradation at a provincial level were calculated using the percentages of areas affected by soil degradation at a national scale in temperate and cloud forests multiply by the total forested areas for each province. To classify these areas into chemical and physical soil degradation, the forested areas affected by soil degradation at the provincial level were multiplied by the average percentages of hectares that were chemically and physically degraded in temperate and cloud forests.

Verkerk et al. [29] sets extraction limits for logging residues coming out of final felling and thinning according to three mobilization scenarios. These extraction rates vary from $0 \%$ to $70 \%$ depending on the observed terrain conditions. Jong et al. [30] argues that the optimal extraction rates at a landscape level for achieving energy values, environmental quality objectives and forest production objectives are $60 \%$ for branches and tops and 10\% for stumps. As this research does not take stumps into consideration as residues for energetic use, extraction limits are referred to the ones developed by Verkerk et al. [29]. Based on this data, Table 12 shows the maximum extraction rates used for the regional case study.

Table 12. Maximum extraction rates

\begin{tabular}{lccc}
\hline Soil Degradation Type & Slight & Moderate & Severe \\
\hline Chemical (soil fertility) & $70 \%$ & $35 \%$ & $0 \%$ \\
Physical (compaction) & $70 \%$ & $25 \%$ & $0 \%$ \\
\hline
\end{tabular}

To calculate the amount of harvested residues in cubic meters technically available, factors were developed using the percentage of degraded forest areas at provincial level and the extraction rates previously presented. Based on available biomass for energetic use calculated in the first research module, these factors were then used to transform the theoretical potential to technically available biomass. Equations (8) and (9) explain the logic behind the calculations of available biomass factors constrained by soil degradation.

$$
\begin{gathered}
\text { Bslight }_{i}=\left[\frac{T f-D_{\text {tot }}+D_{\text {slight }}}{T f}\right] \times \text { Erslight }_{i} \\
\text { Bmoderate }_{i}=\left[\frac{D_{\text {moderate }}}{T f}\right] \times \text { Ermoderate }_{i}
\end{gathered}
$$

where $B$ is the available biomass factor constrained by soil degradation, $T f$ refers to the total forested area of the region (ha), $E r$ is the maximum extraction rate according to scale (Table 2) and $i$ refers either to chemical or physical degradation. 
Equation (8) includes areas with no degradation, which have an extraction limit of $70 \%$. This is reflected by subtracting the total degraded hectares from the total forested area, thus, where no degradation is observed only $70 \%$ of the theoretical available biomass can be utilized for energetic use. Table 2 presents the biomass extraction factors taking into consideration the degraded areas and extraction rates explained in equation 8 and 9.

\section{Extraction Limit according to Slope Class}

In order to calculate the technical biomass constrained by terrain slope condition, a terrain slope class calculation per region, that was based on five slope classes [31], was carried out using GIS spatial analysis (appendix A). The non-extracted stands residues constrained by slope conditions were accounted for by multiplying the share of each slope class by the non-extracted stands biomass residues (NE). Only areas with a slope up to $35 \%$ were considered in the analysis. Subsequently, the extraction limits shown in Table 12 were used for the corresponding soil degradation.

\section{Extraction Limit according to Mechanization Level}

The extraction limits based on the level of mechanization were developed through an analysis of current forest operations techniques on harvesting, with productivity as the analyzed parameter. Productivity is analyzed here in order to estimate a reference point for the effects of the mechanization level on the supply of woody biomass for energetic purposes. Therefore, this research module assumes that the level of mechanization has an impact on harvesting productivities according to the technique and equipment used. The non-extracted stands and the non-extracted stand residues were taken into consideration for this analysis.

The extraction limit based on mechanization level involves the calculation of productivities given equipment, slope percentage at felling site and diameter at breast height $(D B H)$ of the stand to be felled. Productivities given current conditions (equipment, slope class and $D B H$ ) are calculated and set as base line productivities $(B L)$. The rate between the calculated base line productivity and the productivity required to utilize the theoretical available woody biomass from non-extracted stands is set as the extraction limit. That is to say, a rate between the amount of cubic meters per hour currently available according to equipment and machinery and the productivity required to utilize the theoretical woody biomass potential from non-extracted stands is reviewed. In order to set this base line and then apply changes to this variable, a review of forest operations for harvesting in the Mexican context was carried out.

The study "Diagnóstico de las capacidades y situación tecnológica del sector forestal y forestal-industrial del país" (Diagnosis of the capabilities and technology situation of the forest sector and forest industry in the country) [23] describes the development of the Mexican forest technology as follows: Forest operations are mainly supported by manual felling and debranching using chainsaw. Mechanical extraction is observed in the north and the center of the country. However, this mode of extraction has not completely replaced manual extraction. The machinery used for extraction is generally cranes, while some cable yarding projects have begun. Loading is carried out manually and transportation uses 10-12 ton trucks. Hernández et al. [32] reports an extraction system in the north combining a two reel crane with a cable yarding system Koller 300. These authors describe the loading as a process using loading cranes and front loaders. However, the loading is performed manually for short logs. Torton trucks of 18 ton capacity are used to transport long logs and rabon trucks for short logs. The unloading process is mechanized using fixed or mounted cranes and loader trailer. In regard to time studies, in his analysis performed in the State of Mexico, Ávila [33] presents a productivity of $11.55 \mathrm{~m}^{3} / \mathrm{h}$ for harvesting operations, including felling, debranching and bucking using chainsaw in conifers. Table 13 summarizes the results of different time studies and is simultaneously an overview of productivities for calculating the $B L$ value. 
Table 13. List of productivities of manual felling based on time studies in Mexico.

\begin{tabular}{|c|c|c|c|}
\hline Author & $\begin{array}{l}\text { Productivity } \\
\left(\mathrm{m}^{3} / \mathrm{h}\right)\end{array}$ & Place of Study & Comments \\
\hline Zarate [34] & $4-5$ & Average in Mexico & $\begin{array}{l}\text { The activities include felling, debranching } \\
\text { and crosscutting. This value represents } \\
\text { approximately } 25 \text { to } 30 \mathrm{~m}^{3} / \text { day/crew with } \\
2 \text { to } 3 \text { workers per crew }\end{array}$ \\
\hline Luna and Sánchez [35] & 17 & $\begin{array}{l}\text { Durango (MX) } \\
\text { North region }\end{array}$ & $\begin{array}{l}\text { Felling and processing were included with } \\
\text { a distance between trees of } 22.32 \mathrm{~m} \text {. A Stihl } \\
\text { chainsaw of } 5 \mathrm{hp} ., 10 \mathrm{~kg} \text { and } 70 \mathrm{~cm} \text { long for } \\
18 \mathrm{ft} .(5.48 \mathrm{~m}) \text { stands was used }\end{array}$ \\
\hline Ávila [33] & 11.55 & $\begin{array}{l}\text { State of México (MX) } \\
\text { Central region }\end{array}$ & $\begin{array}{l}\text { Felling, debranching and crosscutting are } \\
\text { included within the cycle. A Homelite } 1050 \\
\text { and McCulloch } 850 \text { chainsaw of } 30 \mathrm{in.} \\
(0.762 \mathrm{~m}) \text { long were used in the study. } \\
\text { Conifers of the region were harvested }\end{array}$ \\
\hline Frausto [36] & 6.15 & $\begin{array}{l}\text { Puebla (MX) } \\
\text { Central region }\end{array}$ & $\begin{array}{l}\text { Preparing, transfer, clearing felling zone, } \\
\text { felling, debranching, chopping and } \\
\text { pre-skidding were the analyzed activities. } \\
\text { The utilized species was pine using a Stihl } \\
051 \mathrm{AV} \text { chainsaw at a } 30 \% \text { average slope }\end{array}$ \\
\hline
\end{tabular}

The harvesting cycle in the present research includes felling, debranching and bucking. Therefore, Equation (10) presents productivities $B L$ in manual harvesting operating with chainsaws for pine, oak and fir (adapted from Sacchelli et al. [37]). As shown in Equation (11), a D factor is calculated based on harvesting coefficients, affecting productivities according to the amount of biomass residues from harvesting activities. Pine productivity was set as the reference productivity. The residue coefficient value from harvesting is assumed to have a proportional weight on productivity. Higher coefficients, assuming more branches and residues, affect productivities to a higher degree.

$$
\begin{gathered}
\operatorname{Pr}_{i}=\left[\frac{42-2.6 \times D B H}{-20} \times 1.65\left[1-\frac{S l}{100}\right]\right] \times D_{i} \\
D_{i}=1+\left(C_{i}-C_{\text {pine }}\right)
\end{gathered}
$$

where $\mathrm{Pr}$ is the productivity of manual felling using chainsaw, $S l$ is the slope percentage at the felling site, $D B H$ correspond to the diameter at breast height $(\mathrm{cm})$ and $D$ is the correction factor based on $C$ as coefficient residue from harvesting for a species $i$.

It is of relevance to note that the estimated productivity $P r_{i}$, without the $D$ factor, is identical to the round wood biomass as final product, if branches and residues are not considered. The $D$ factor allows for a difference between species by focusing on the amount of branches at felled tree, assuming that the productivity is estimated for the two final products of round wood and residues from debranching. Thus, given a certain productivity through identical conditions on equipment, slope class and $D B H$ at the felling site but without taking into consideration the $D$ factor, the resulting productivities estimates will be the same for all analyzed species. The $D$ factor includes differences between species based on amount of residues in the form of branches, allowing the model to analyze harvesting productivities involving woody biomass residues for energetic use. Applying equations 10 and 11, Table 14 presents the harvesting productivities using chainsaws for the Mexican context.

Using this data, productivities with $35 \mathrm{~cm}$ of $D B H$ were set as $B L$. Since the model is based on yearly production, a production schedule of 7 months with 5 days per week and 8 hours per day was assumed. Then the required productivity to harvest the theoretical biomass from non-extracted stands per year was compared with the $B L$ productivity that accounts for extraction limits. 
Table 14. Productivities for manual felling using chainsaw according to species, slope class, $D B H$ and $D$ factor $\left(\mathrm{m}^{3} / \mathrm{h}\right)$.

\begin{tabular}{ccccccc}
\hline \multirow{2}{*}{ Species } & \multirow{2}{*}{ Slope (\%) } & \multicolumn{5}{c}{$\boldsymbol{D B H}(\mathbf{c m})$} \\
\cline { 3 - 7 } & & $\mathbf{3 0}$ & $\mathbf{3 5}(\mathbf{B L})$ & $\mathbf{4 0}$ & $\mathbf{4 5}$ & $\mathbf{5 0}$ \\
\hline Pine & \multirow{2}{*}{20} & 2.38 & 3.23 & 4.09 & 4.95 & 5.81 \\
Oak & 2.78 & 3.78 & 4.79 & 5.79 & 6.80 \\
Fir & & 2.40 & 3.27 & 4.13 & 5.00 & 5.87 \\
Pine & & 1.93 & 2.63 & 3.32 & 4.02 & 4.72 \\
Oak & \multirow{2}{*}{35} & 2.26 & 3.07 & 3.89 & 4.71 & 5.52 \\
Fir & & 1.95 & 2.65 & 3.36 & 4.06 & 4.77 \\
Pine & & 1.49 & 2.02 & 2.56 & 3.09 & 3.63 \\
Oak & \multirow{2}{*}{50} & 1.74 & 2.36 & 2.99 & 3.62 & 4.25 \\
Fir & & 1.50 & 2.04 & 2.58 & 3.12 & 3.67 \\
\hline
\end{tabular}

An estimate of available non-extracted biomass according to slope class was developed to then calculate the productivity required to utilize this biomass within the mentioned production schedule. The comparison between this required productivity and the given productivities $(B L)$ resulted in the extraction limits per slope class and species. Averages were calculated for each species and region to set extraction limits according to the mechanization level (Table 15).

Table 15. Extraction limits for non-extracted stands constrained by mechanization level.

\begin{tabular}{cccc}
\hline Region & Pine & Oak & Fir \\
\hline North & $3 \%$ & $10 \%$ & - \\
Central-south & $5 \%$ & $14 \%$ & $52 \%$ \\
\hline
\end{tabular}

Estimation of Associated Cost for Utilizing Available Woody Biomass for Energetic Use

In order to estimate the economic potential of the regionally supplied woody biomass for energy use, the harvesting and transportation costs for utilizing the available forest woody biomass for energetic use were calculated. Data from 27 community forest enterprises, distributed on 12 provinces along the country was used to estimate costs [24].

Due to variations in analyzed costs between and within regions, and in order to represent the uncertainties of these costs in the model, Monte Carlo simulations were carried out. Using statistical sampling to represent uncertainties by specifying inputs as probabilistic distributions, the estimation of associated costs for utilizing available woody biomass for energetic use was performed using the Monte Carlo method. These uncertainties are observed in the model as differences between the economic performance of the forest sector in the north and central-south region, as well as parameters such as transportation distance, infrastructure and market development. Probability distributions impact the involved variables and a specific outcome to occur with different probabilities. That is to say, when describing the more realistic uncertainties of a variable within an analysis, probability distributions are used. Discrete event simulation uses mathematical analytical frameworks focusing on specific points in a certain time of simulation, for predicting and monitoring trends or any other behaviors. On the other hand, Mote Carlo simulations utilizes models of uncertainty where representation of time is unnecessary. Because the analysis was done for the year 2013 as status quo, discrete simulation was not considered. When analyzing the costs of this research, a uniform and a triangular probability distribution are used

As there is no established market in Mexico for woody biomass residues, nor are the prices or the cost for their utilization, the costs for utilizing the analyzed residues are assumed to be equal to the existing costs for round wood production. These costs include: (1) labor cost from harvesting and extraction, (2) labor cost from machine operation, (3) road maintenance and construction cost, 
(4) transportation cost and (5) technical support cost. The availability of biomass residues from harvesting activities takes cost (1), (2) and (4) into account. The cost of utilizing available biomass residues from non-extracted stands was based on all costs (1-5) mentioned above. For the availability of biomass residues from sawmills, (2) and (4) were used. Each cost is set to be independent of the others, i.e., its distribution does not affect any other variable value. All variables are independent. Assuming that the most probable value will occur between a minimum and maximum number with the same probability, a uniform distribution was used for all the analyzed costs within the northern region. For the central south region, information on maximum, minimum and most occurred values (mode) for the transportation cost was available. Therefore, in this case a triangular probability function was used. Table 16 presents a summary of the cost samples for each region.

Table 16. Statistics parameters from sampled data according to cost and region.

\begin{tabular}{|c|c|c|c|c|c|}
\hline Region & Labor Cost & $\begin{array}{c}\text { Machine } \\
\text { Operation Cost }\end{array}$ & $\begin{array}{c}\text { Road } \\
\text { Construction Cost }\end{array}$ & $\begin{array}{c}\text { Transportation } \\
\text { Cost }\end{array}$ & $\begin{array}{c}\text { Technical } \\
\text { Support Cost }\end{array}$ \\
\hline North $n=7$ & MXN/m ${ }^{3}$ & $\mathrm{MXN} / \mathrm{m}^{3}$ & $\mathrm{MXN} / \mathrm{m}^{3}$ & $\mathrm{MXN} / \mathrm{m}^{3}$ & $\mathrm{MXN} / \mathrm{m}^{3}$ \\
\hline Min & 9 & 28 & 1 & 87 & 12 \\
\hline Max & 211 & 245 & 87 & 317 & 62 \\
\hline Range & 202 & 217 & 86 & 230 & 50 \\
\hline $\begin{array}{l}\text { Standard } \\
\text { deviation }\end{array}$ & 68.64 & 82.56 & 29.52 & 87.22 & 20.23 \\
\hline Mean & 65.00 & 162.43 & 22.00 & 170.43 & 40.29 \\
\hline \multicolumn{6}{|l|}{$\begin{array}{c}\text { Central-south } \\
n=20\end{array}$} \\
\hline Min & 27 & 1 & 0 & 80 & 1 \\
\hline Max & 1189 & 546 & 74 & 576 & 243 \\
\hline Range & 1162 & 545 & 74 & 496 & 242 \\
\hline $\begin{array}{l}\text { Standard } \\
\text { deviation }\end{array}$ & 261.53 & 155.04 & 21.51 & 112.66 & 67.34 \\
\hline Mean & 222.80 & 154.25 & 27.15 & 241.00 & 78.05 \\
\hline
\end{tabular}

When analyzing the regions individually, Figure 4 shows that the skewness of labor costs for the northern region has an asymmetry with a larger size in the lower part of the box, meaning that the range of values for labor cost below its mean $\left(54 \mathrm{MXN} / \mathrm{m}^{3}\right)$ is greater than the range of higher cost values. Values for the labor cost and the road construction cost show sample points more than 1.5 times the interquartile range above the third quartile, specifically the outliers for the values $211 \mathrm{MXN} / \mathrm{m}^{3}$ and $87 \mathrm{MXN} / \mathrm{m}^{3}$, respectively. On the other hand, the central south region presents significantly higher cost than the north, with the range of values above their mean greater than the range of lower values. Transportation costs are an exception of this case. As shown in Figure 5, outliers in the central south region are present in labor cost, machine operation cost, technical support cost and transportation cost. These outliers, as atypical values, are analyzed for developing a correct Monte Carlo analysis. Furthermore, both figures present mean values as white diamonds for each variable cost.

Figure 6 compares the average costs values between the two regions, based on the 27 sampled enterprises. The highest difference between regions is found for the labor cost, where the mean for the central south region is more than double the mean of the north. For both regions, transportation is the highest cost in utilizing forest woody biomass. The difference could be explained by the ownership of the transportation equipment, low integration between forest areas and transformation centers, long distances between forest and end-use points and poor conditions of roads infrastructure. The small share of road construction costs is also related to the high transportation costs, since the low investment in road construction results in poor infrastructure. Once the expected value from each cost is estimated using Monte Carlo analysis, the costs are totaled according to harvesting residues, non-extracted stands residues and sawmill residues. This involves three values that represent the utilization of available biomass for energetic use from (1) harvesting residues, (2) non-extracted stand residues and (3) sawmills residues. 


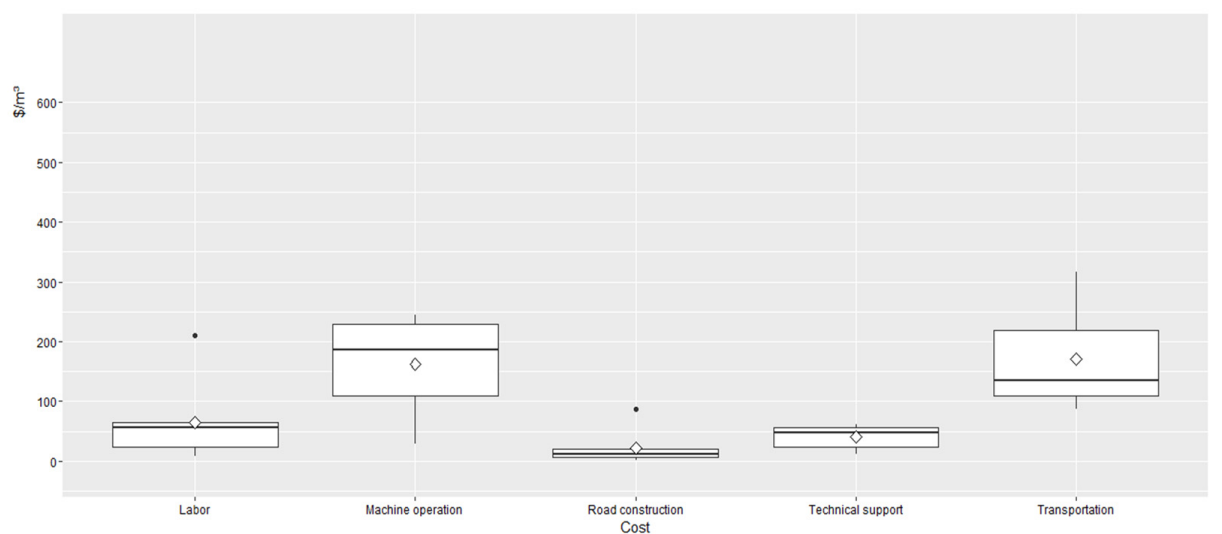

Figure 4. Boxplot of sampled variable cost for the northern region $(n=7)$ summarizing distribution, mean, median, skewness and outliers.

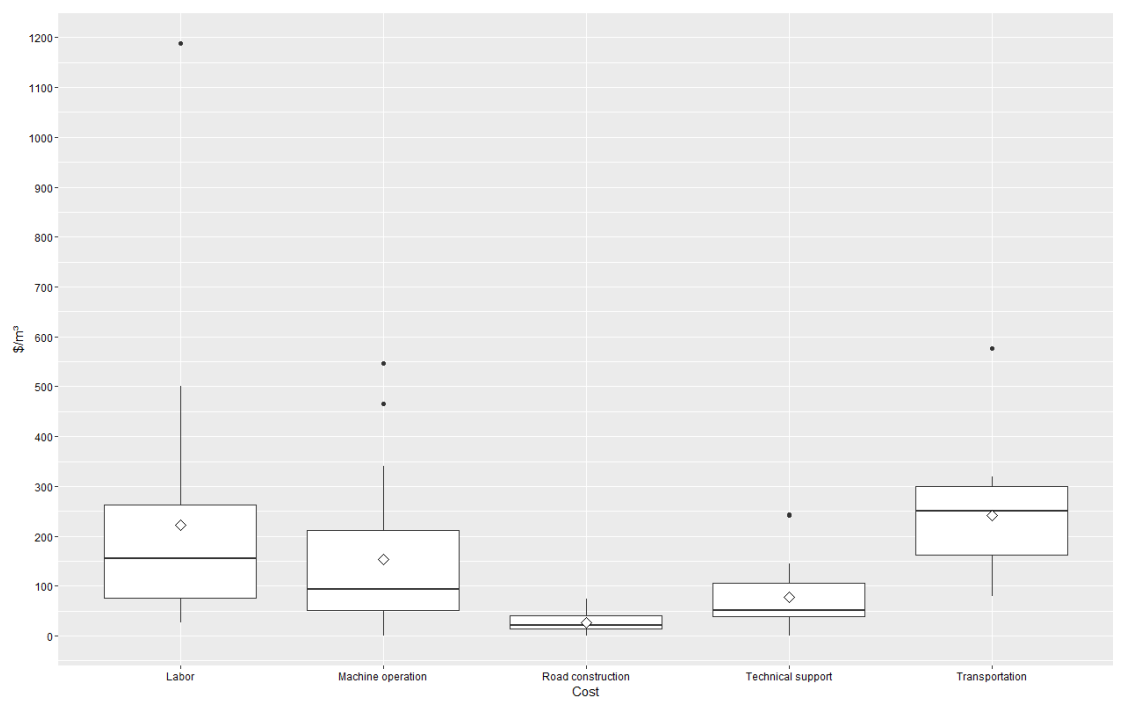

Figure 5. Boxplot of sampled variable cost for the central south region $(n=20)$ summarizing distribution, mean, median, skewness and outliers.

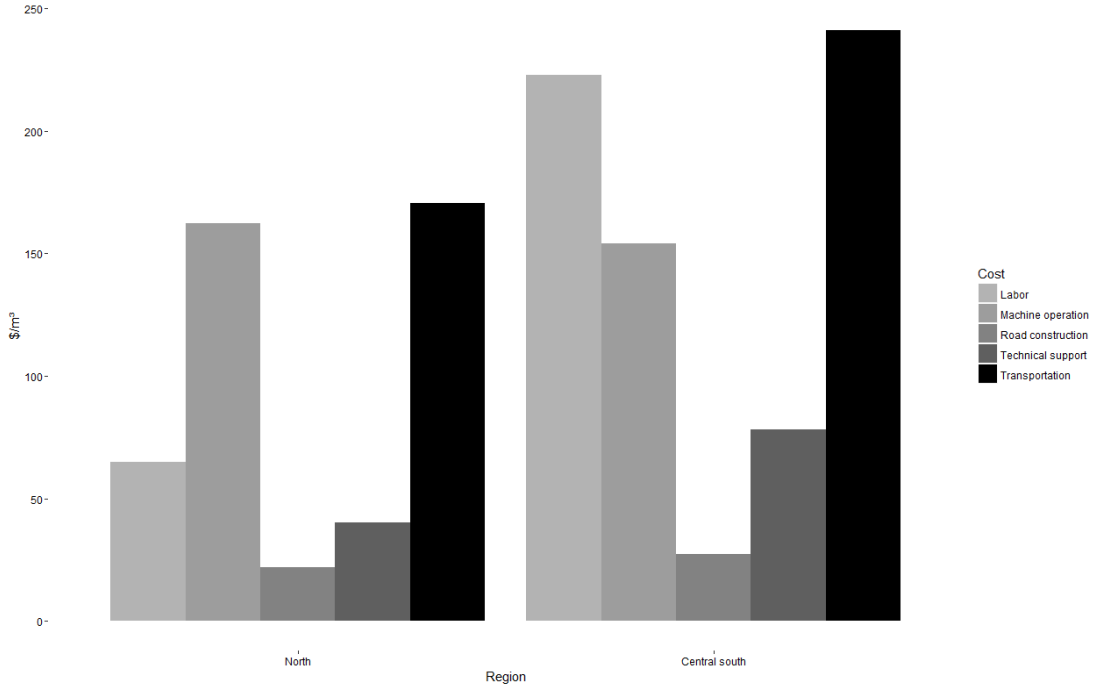

Figure 6. Mean values of analyzed costs for north and central south region. 


\subsubsection{Energy Output}

Using the calculations carried out in the first research module, a biomass energy flow chart is developed to trace biomass production for energetic use from the analyzed sources. The theoretically available volume of potential woody biomass and the related energy values are calculated based on its source (harvesting residues, non-extracted residues and sawmill residues). Figure 7 presents a breakdown of biomass production for energetic use to show the origins of residues. Percentages based on the total production from 2013 as standing volume are presented as well. This breakdown complements the biomass energy flow chart, which shows aboveground biomass production and utilization of the selected sources for the north and central south region. Information regarding total theoretically available biomass for energetic use and utilization levels is presented by the biomass energy flow chart [38]. It is important to note that the biomass energy flow chart only accounts for national production from the analyzed sources, excluding imports. As it is the moisture content rather than the species that determines energy availability, a net heating value of $16.0 \mathrm{GJ} / \mathrm{t}$ is set. This assumes air-dry wood with $15 \%$ of moisture content dry basis [38]. Basic densities were set to $0.487 \mathrm{t} / \mathrm{m}^{3}$, $0.740 \mathrm{t} / \mathrm{m}^{3}$ and $0.380 \mathrm{t} / \mathrm{m}^{3}$ for pine, oak and fir respectively [26]. After constraints have been applied to account for the technical potential of available forest woody biomass, energy values are estimated according to lower heating value. In order to assess the status quo, the technically available biomass for energetic use constrained by soil degradation, slope percentage and mechanization level is estimated.

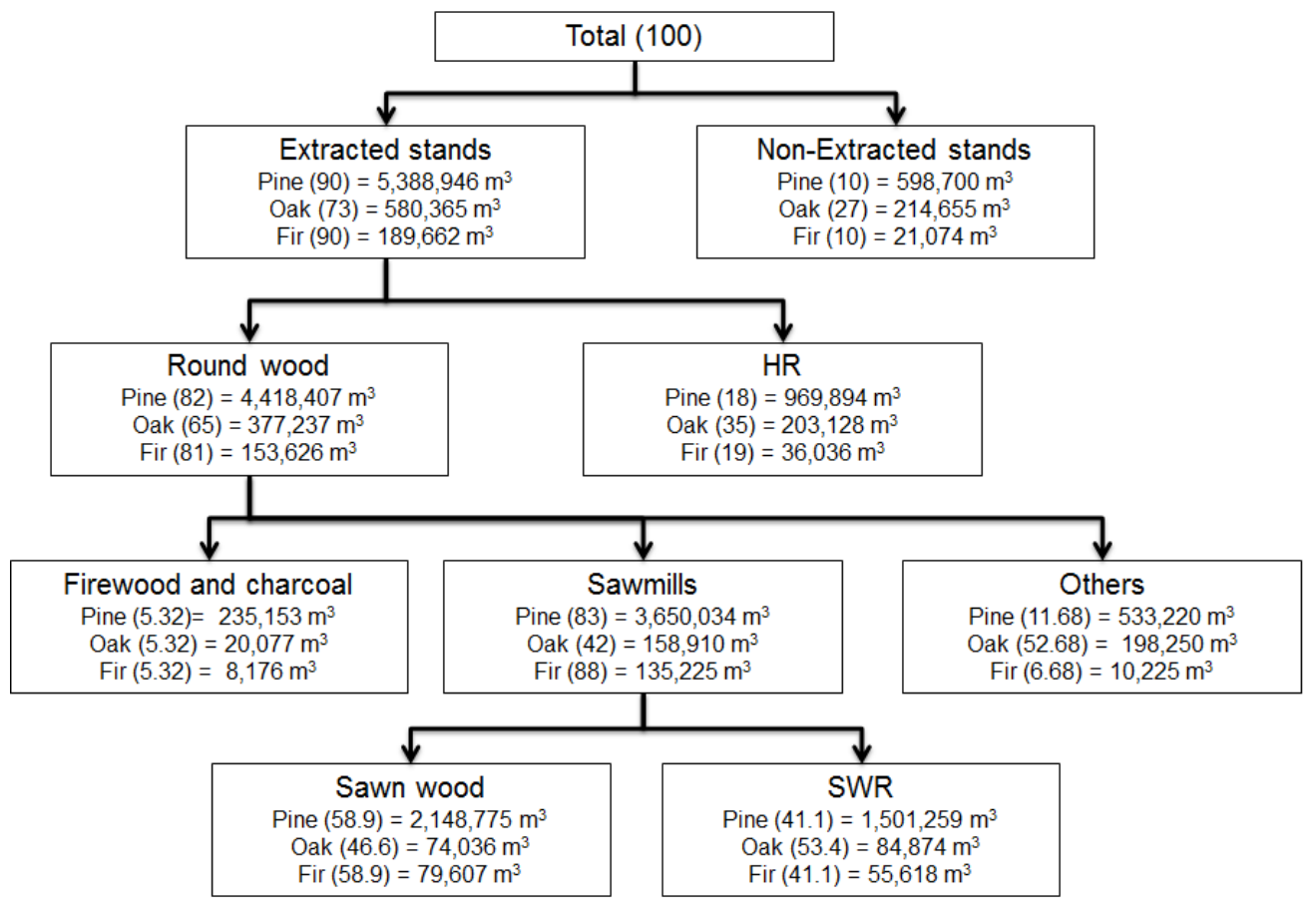

Figure 7. Breakdown of biomass production for energetic use showing residues origin from the 10 analyzed provinces. Notes: "Total" refers to total available woody biomass as standing volume from the 10 analyzed provinces in 2013. The values in parentheses are percentages of the previous category. HR: residues coming from harvesting activities. SMR: produced residues after sawmill processes. Non-extracted stands, as available but not utilized resources, are considered to be a plus for biomass utilization.

\section{Conclusions}

In recently developed renewable energies projects at a national level, analyses of the potential diversification of energy supply chains in Mexico have principally focused on solar power, wind energy and some other biomass sources, barely considering the advantages of sustainable forest resources as 
source of bioenergy for rural communities. There has been little research carried out on the adapting the forest value chain for bioenergy purposes. A few studies have analyzed the potential for energy from forest biomass mainly for the northern part of Mexico, where most of the woody biomass is produced. The creation of new forest wood supply chains, including bioenergy supply, opens a range of opportunities for sustainable forest management and sustainable forest utilization.

Thus, an analysis of the theoretical, technical, economic and sustainable potential of decentralized energy generation based on woody biomass is addressed within the presented methodology along with its impacts, comprising of biomass production, biomass management and biomass supply. The technical potential calculated with this methodology considers constraints affecting forest management and forest operations. It analyses the potential of forest woody biomass in an integrated assessment of the forest sector towards bioenergy supply. The research design is supported by an analysis of harvesting operations for evaluating scenarios for bioenergy supply based on cost, mechanization level, soil degradation and slope percentage. Therefore, it considers forest management criteria as sustainability constraints based on extraction limits to calculate the technically available biomass for energetic use, including estimations of productivities according to the mechanization level. Additionally, it enables scenario analysis based on changes in the harvesting practices of forest operations. The three research modules address variables for analyzing the feasibility of decentralized bioenergy generation, taking into account the inputs, outputs and processes involved in energy utilization.

Several papers regarding the assessment of forest biomass supply chains present and discuss frameworks for modeling variables which estimates output in terms of biomass availability, costs and C stocks and fluxes. For instances Sacchelli et al. [37], Schelhaas et al. [39], Sokhansanj et al. [40], Masera et al. [41] and Alemán-Nava et al. [42], among others, suggest simulation methods which incorporate variables according to a given analysis context. For the research design, the presented study takes into consideration these and other investigations, having a focus on biomass extraction limits which are based on forest operations criteria at a local context. Additionally to the frameworks, methods and tools of these studies, and based on available national and regional data, this paper proposes an evaluation of the Mexican forest sector with a special approach on forest operations for bioenergy supply.

Within a national context, this research aims to provide new findings and knowledge for the development of methodologies for designing and analyzing energy projects based on biomass. The purpose is to evaluate scenarios for the sustainable utilization of forest resources, which set to identify effective bioenergy supply chains. An analysis of the use of local resources founded on renewable inputs intends to set the basis for creating local value chains within the rural sector. In the absence of robust data, an assessment of the forest sector conditions for a sustainable utilization of lignocellulose biomass for energetic use, including forest management and forest operations, adds innovation to the research in Mexico, where bioenergy generation from forest resources have not been yet fully analyzed.

Acknowledgments: This research project was supported by the Deutscher Akademischer Austauschdienst (DAAD) as part of the scholarship program Forschungsstipendien für Doktoranden und Nachwuchswissenschaftler für mehr als 6 Monate, 2014/15 (57048249). The article processing charge was funded by the German Research Foundation (DFG) and the University of Freiburg in the funding programme Open Access Publishing.

Author Contributions: Ulises Flores Hernández conceived and designed the experiments, performed the experiments and analyzed the data; Dirk Jaeger and Jorge Islas Samperio contributed reagents/materials/analysis tools; Ulises Flores Hernández wrote the paper with input of Dirk Jaeger.

Conflicts of Interest: The authors declare no conflict of interest. The founding sponsors had no role in the design of the study; in the collection, analyses, or interpretation of data; in the writing of the manuscript, and in the decision to publish the results. 


\section{Appendix A}

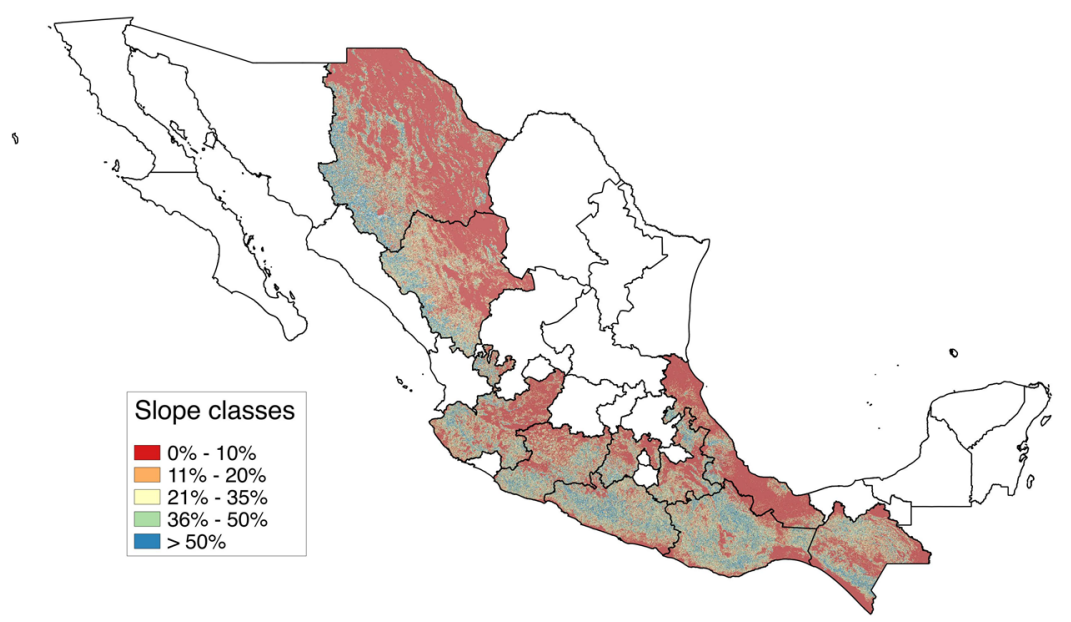

Figure A1. Slope classes in analyzed provinces.

\section{References}

1. Instituto Nacional de Estadística y Geografía INEGI. Censo Agropecuario: Censo Ejidal; Instituto Nacional de Estadística y Geografía INEGI: Aguascalientes, Mexico, 2007.

2. Comisión Nacional Forestal CONAFOR. Logros y perspectivas del desarrollo forestal en México 2007-2012; Comisión Nacional Forestal CONAFOR: Jalisco, Mexico, 2013.

3. Secretaría de Gobernación SEGOB (2014): Diario Oficial de la Federación. Mexico. Available online: http:/ / www.dof.gob.mx/ (accessed on 9 August 2017).

4. Comisión Nacional para el Conocimiento y Uso de la Biodiversidad CONABIO. La biodiversidad forestal de México. Mexico. Available online: http:/ /www.conabio.gob.mx/institucion/cooperacion_internacional/ doctos/dbf_mexico.html (accessed on 9 August 2017).

5. Secretaría de Energía SENER. Prospectiva de Energías Renovables 2013-2027; Secretaría de Energía SENER: Ciudad de México, Mexico, 2013.

6. Comisión Nacional de Electricidad CFE. Informe Anual 2013; Comisión Nacional de Electricidad CFE: Mexico City, Mexico, 2013.

7. Secretaría del Medio Ambiente y Recursos Naturales SEMARNAT. Anuarios Estadísticos de la Producción Forestal 2003-2013. Available online: http:/ / www.semarnat.gob.mx/temas/gestion-ambiental/forestal-ysuelos/anuarios-forestales (accessed on 9 August 2017).

8. Comisión Nacional Forestal CONAFOR. Información Estadística de la Producción Forestal Nacional 2015. Mexico. Comisión Nacional Forestal CONAFOR. Available online: http:/ /www.cnf.gob.mx:8090/snif/ portal/economica/estadistica-forestal-nacional (accessed on 9 August 2017).

9. Sessions, J.; Boston, K.; Murphy, G.; Wing, M.G.; Kellogg, L.; Pilkerton, S.; Heinrich, R. Harvesting Operations in the Tropics; Springer: Berlin, Germany, 2007.

10. Diario Oficial de la Federación. Available online: http://www.dof.gob.mx/indicadores.php (accessed on 9 August 2017).

11. Torres, J. Estudio de Tendencias y Perspectivas del Sector Forestal en América Latina Documento de Trabajo; Food and Agriculture Organization of the United Nations (FAO): Rome, Italy, 2004.

12. Food and Agriculture Organization of the United Nations FAO. Global Forest Resources Assessment FRA 2010; Food and Agriculture Organization (FAO): Rome, Italy, 2011.

13. Comisión Nacional Forestal CONAFOR. Programa Estratégico Forestal para México 2025. Comisión Nacional Forestal CONAFOR. Available online: https: / /www.google.com.sg/url?sa=t\&rct=j\&q=\&esrc=s\& source=web\&cd=1\&ved=0ahUKEwjBxtSxy8vVAhWKKZQKHQLdAloQFggkMAA\&url=http $\% 3 \mathrm{~A} \% 2 \mathrm{~F} \%$ 2Fera-mx.org\%2Fbiblio\%2FPEF_2025.pdf\&usg=AFQjCNG343htMINb2h4O1SymesOW69HOpg (accessed on 9 August 2017). 
14. Secretaría de Energía SENER. Balance Nacional de Energía 2014; Secretaría de Energía SENER: Ciudad de México, Mexico, 2015.

15. Jaakko Pöyry Consulting. Estudio de Prefactibilidad de la Cuenca Industrial Forestal del Golfo de México; Jaakko Pöyry Consulting: Guadalajara, Mexico, 2009.

16. Islas, J.; Manzini, F.; Masera, O. A prospective study of bioenergy use in Mexico. Energy 2006, 32, $2306-2320$. [CrossRef]

17. García, C.; Riegelhaupt, E.; Ghilardi, A.; Skutsch, M.; Islas, J.; Manzini, F.; Masera, O. Sustainable bioenergy options for Mexico: GHG mitigation and costs. Renew. Sustain. Energy Rev. 2015, 43, 545-552. [CrossRef]

18. Rios, M.; Kaltschmitt, M. Bioenergy potential in Mexico-status and perspectives on a high spatial distribution. Biomass Convers. Biorefinery 2013, 3, 239-254. [CrossRef]

19. Centro de Negocios Forestales CENEFOR Precios de productos forestales maderables. Reporte trimestral Octubre/Diciembre 2013. Mexico. Centro de Negocios Forestales CENEFOR. Available online: http: / / www.cnf.gob.mx:8090/snif/portal/economica/sipre (accessed on 9 August 2017).

20. Sánchez, L. El consumo energético de los hogares en México. Coyuntura Demográfica 2012, 2, 81-86.

21. Masera, O.; Ordoñez, J.M.; Dirzo, R. Carbon emissions from deforestation in Mexico: current situations and long term scenarios. Clim. Chang. 1997, 35, 265-295. [CrossRef]

22. Instituto Nacional de Estadística y Geografía INEGI (2016). Available online: http:/ / www.inegi.org.mx/ default.aspx (accessed on 9 August 2017).

23. Flores, H.; Garduño, M.; Arroyo, C.; Gomez, E. Diagnóstico de las Capacidades y Situación Tecnológica del Sector Forestal y Forestal-Industrial del país. Eje 4 innovación y diseño; Universidad de Guadalajara: Guadalajara, Mexico, 2014.

24. Cubbage, F.; Davis, R.; Rodríguez, D.; Frey, G.; Mollenhauer, R.; Kraus, Y.; González, I.; Albarrán, H.; Salazar, A.; Chemor, D. Competitividad y Acceso a Mercados de Empresas Forestales Comunitarias en México; Programa sobre los Bosques PROFOR: Mexico City, Mexico, 2013.

25. Instituto Nacional de Investigaciones Forestales Agrícolas y Pecuarias INIFAP. Determinación del Potencial y Aprovechamiento de los Residuos Forestales en la Producción de Bioenergía y de Especies no Aprovechadas en el Manejo Forestal; Instituto Nacional de Investigaciones Forestales, Agrícolas y Pecuarias INIFAP: Mexico City, Mexico, 2012.

26. World Agroforestry Center, Tree Functional Attributes and Ecological Database. Available online: http: / / db.worldagroforestry.org/ (accessed on 9 August 2017).

27. Secretaría del Medio Ambiente y Recursos Naturales SEMARNAT. Evaluación de la Degradación del Suelo Causada por el Hombre en la República Mexicana; Secretaría del Medio Ambiente y Recursos Naturales SEMARNAT: Mexico City, Mexico, 2003.

28. Oldeman, L.R. Guidelines for General Assessment of the Status of Human-Induced Soil Degradation: Global Assessment of Soil Degradation GLASOD; International Soil Reference and Information Centre (ISRIC): Wageningen, The Netherlands, 1988.

29. Verkerk, P.J.; Anttila, P.; Eggers, J.; Lindner, M.; Asikainen, A. The realisable potential supply of wood biomass from forests in the European Union. For. Ecol. Manag. 2011, 261, 2007-2015. [CrossRef]

30. de Jong, J.; Akselsson, C.; Berglund, H.; Egnell, G. Consequences of an Increased Extraction of Forest Biofuel in Sweden-A Synthesis from the Biofuel Research Programme 2007-201. Summary of the Synthesis Report; The Swedish Energy Agency: Eskilstuna, Sweden, 2014.

31. Berg, Staffan (Ed.) Terrain Classification System for Forestry Work; Forest Operations Institute "Skogsarbeiten": Stockholm, Sweden, 1992.

32. Hernández, D.; Alcazar, V.; Unzueta, A.; Sánchez, Q. Arrime de Trocería Combinando los Sistemas de Motogrúa y Cable Aéreo; Universidad Juárez del Estado de Durango: Durango, Mexico, 2002.

33. Ávila, A. Análisis de Producción y Costos de las Operaciones de Abastecimiento en la Unidad de Administración Forestal No.2 Valle de Bravo, Estado de México; Universidad Autónoma Chapingo: Texcoco, Mexico, 1983.

34. Zarate, D. Propuesta Metodológica Para Análisis de Costos en Abastecimiento Forestal; Universidad Autónoma Chapingo: Texcoco, Mexico, 2012.

35. Luna, P.; Sánchez, M. Evaluación Operacional y Ambiental del Abastecimiento Forestal en el Ejido San Pablo, Pueblo Nuevo, Durango; Instituto Tecnológico de El Salto: Durango, Mexico, 2008.

36. Frausto, L. Extracción de Trozas con Tecnología Apropiada en Bosques de Chignahuapan; Universidad Autónoma Chapingo: Texcoco, Mexico, 1990. 
37. Sacchelli, S.; Zambelli, P.; Zatelli, P.; Ciolli, M. Biomasfor: an open-source holistic model for the assessment of sustainable forest bioenergy. iFo. Biogeosci. For. 2013, 6, 285-293. [CrossRef]

38. Rosillo-Calle, F.; Woods, J. The Biomass Assessment Handbook. Bioenergy for a Sustainable Environment; Earthscan: London, UK, 2012.

39. Schelhaas, M.J.; van Esch, P.W.; Groen, T.A.; de Jong, B.H.J.; Kanninen, M.; Liski, J.; Masera, O.; Mohren, G.M.J.; Nabuurs, J.; Palosuo, T.; et al. CO2FIX V 3.1 - A Modelling Framework for Quantifying Carbon Sequestration in Forest Ecosystems; ALTERRA: Wageningen, The Netherlands, 2004.

40. Sokhansanj, S.; Kumar, A.; Turhollow, A.F. Development and implementation of integrated biomass supply analysis and logistics model (IBSAL). Biomass Bionergy. 2006, 30, 838-847. [CrossRef]

41. Masera, O.; Guerrero, G.; Ghilardi, A.; Velázquez, A.; Mas, J.; Ordoñez, M.D.J.; Drigo, R.; Trossero, M.A. Fuelwood "Hot Spots" in Mexico: A case study using WISDOM-Woodfuel Integrated Supply-Demand Overview Mapping; Food and Agriculture Organization: Rome, Italy, 2004.

42. Alemán-Nava, G.; Meneses-Jácome, A.; Cárdenas-Chávez, D.; Díaz-Chavez, R.; Scarlat, N.; Dallemand, J.; Ornelas-Soto, N.; García-Arrazola, R.; Parra, R. Bioenergy in Mexico: Status and perspective. Biofuels, Bioprod. Biorefining 2015, 9, 8-20.

(C) 2017 by the authors. Licensee MDPI, Basel, Switzerland. This article is an open access article distributed under the terms and conditions of the Creative Commons Attribution (CC BY) license (http://creativecommons.org/licenses/by/4.0/). 